\title{
BEHAVIOR OF REINFORCED HIGH AND ULTRA HIGH STRENGTH CONCRETE BEAMS
}

By

\section{Shahid Mohammad Neaz}

B.Eng. Civil Engineering, Ryerson University, Toronto, 2009

\author{
A project \\ presented to Ryerson University \\ in partial fulfillment of the degree of \\ Mașter of Engineering \\ In the Program of \\ Civil Engineering
}

Toronto, Ontario, Canada, 2011

PROPERTY OF

CShahid Mohammad Neaz, 2011 RYERSON UNIVERGITYLIBRARY 


\section{Author's Declaration Page}

I hereby declare that I am the sole author of this project.

I authorize Ryerson University to lend this project to other institutions or individuals for the purpose of scholarly research.

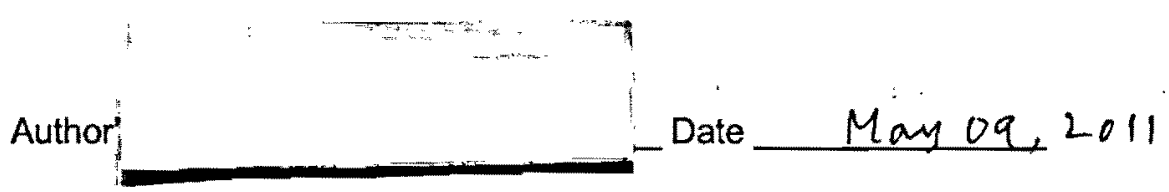

I further authorize Ryerson University to reproduce this project by photocopying or by other means, in total or in part, at the request of other institutions or individuals for the purpose of scholarly research.

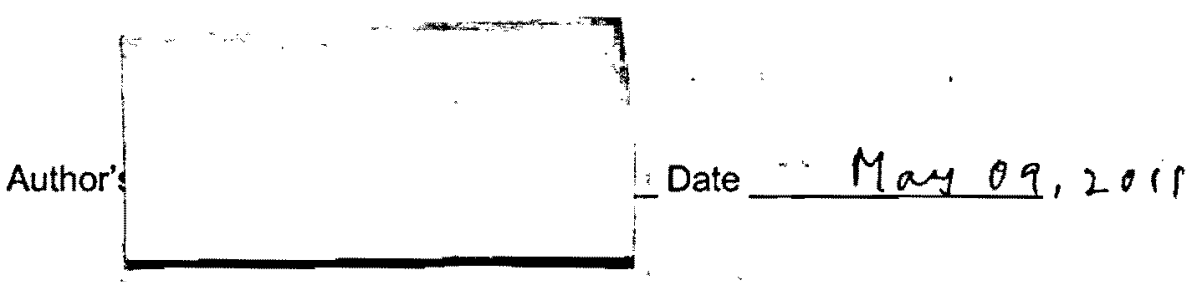




\section{Borrowers}

Ryerson University requires the signatures of all persons using or photocopying this project. Please sign below and give address and date.

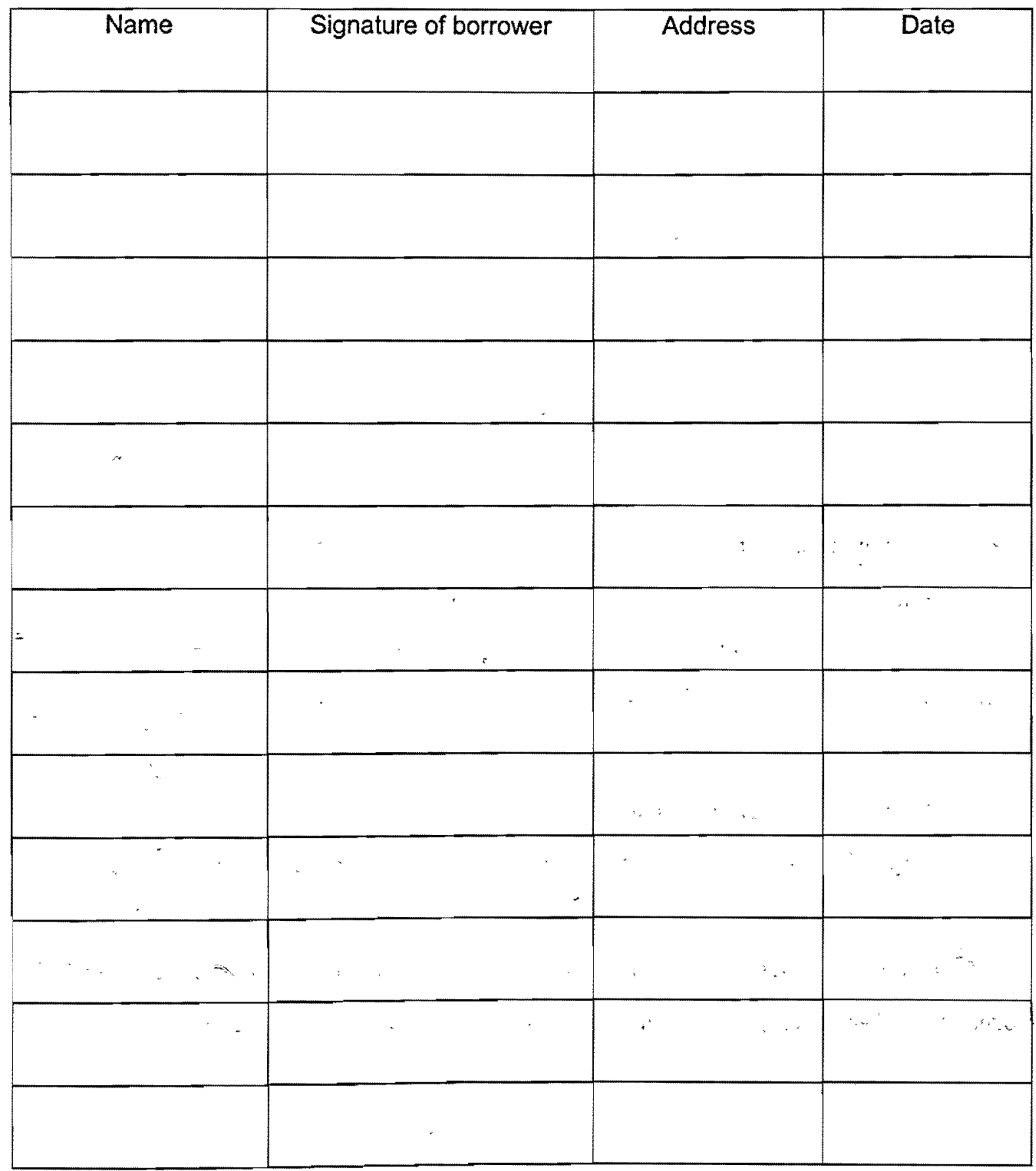




\title{
BEHAVIOR OF REINFORCED HIGH AND ULTRA HIGH STRENGTH CONCRETE BEAMS
}

\author{
Shahid Mohammad Neaz \\ Master of Engineering, Civil Engineering \\ Ryerson University, Toronto, Canada, 2011
}

\begin{abstract}
Load-deflection behaviour of reinforced beams with high strength concrete (HSC) and ultra high strength concrete (UHSC) were studied based on experimental investigations. Four concretes including one HSC and three UHSC were considered for construction of beam specimens. Two different cross-sections of reinforced beams namely Type A and Type B. were considered for testing under single point loading. In addition, three sets of Type B beam were tested with three different shear span to depth ratio (a/d) for each concrete mix. The test results confirmed that flexural strength of fibre reinforced concrete increases with the increase of compressive strength . of concrete and the initial stiffness of UHSC are very high compared to HSC. It was observed that Type B beam with a/d ratio less than 2 show the pattern of shear failure. As such, a theoretical model was studied to verify the performance and the shear load capacity of beams.
\end{abstract}




\section{Acknowledgements}

I would like to express my sincere and deepest gratitude to my supervisor Dr. Khandaker M Anwar Hossain for his guidance and support throughout the project. Though the project was a tough one, it was possible to finish it in time only for his encouragement.

I would like to thank Mr. Nidal Jaalouk, Lead Technical Officer and Mr. Aldardari, Civil Technologists for their assistance throughout the project. Also, I would like to express my special thank to Mr. Ramesh Khatiwada, a third year student and Research Assistant, without whose help I would not have made it possible.

Finally, special gratitude to my family for their constant support and sacrifice during this journey. 
Dedicated To My Family

vi 


\section{Table of Contents}

Author's Declaration Page ___ if

Borrowers -.._- iil

Abstract -

Acknowledgements - $v$

Dedication - vi

Table of Contents- vii

Notations - ix

Chapter 1: Introduction

1.1 Introduction - 1

1.2 Project Objectives —__ 2

1.3 Project Overview - 2

Chapter 2: Background, Literature Review and Design Codes

2.1 High-Performance Concrete

2.2 Ultra High-Performance Concrete

2.2.1 Ductility - 4

2.2.2 Durability 5

2.3 Flexure Design of Fibre Reinforced Concrete 6

2.3.1 Strain-Softening FRC Model - 6

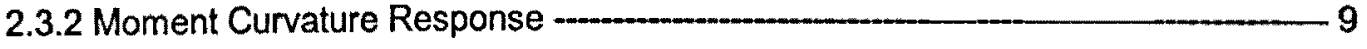

2.3.3 Ultimate Moment Capacity _-_ 11

2.3.4 Deflection Calculation for Serviceability _-_ 11 
2.4 Shear Strength of High-Performance FRC

2.4.1 Narayan and Darwish (1987) Model - 13

2.4.2 RILEM TC 162-TDF 2000 Model 13

2.4.3 Majdzadeh et al. (2005) Model - 14

2.4.4 Summary - 15

\section{Chapter 3: Experimental Program}

3.1 Materials

3.2 Geometry of Test Specimens - 19

3.3 Test Variables 20

3.4 Testing - 20

Chapter 4: Experimental Results

4.1 General 22

4.2 Tests Results 22

4.3 Failure Modes 24

Chapter 5: Analysis of Experimental Results

5.1 Effect of Concrete Type/Strength on Load-Deflection Response of Beam

5.2 Analysis with Theoretical Model and Comparison 28

Chapter 6: Conclusion and Recommendations

6.1 Conclusion 31

6.2 Recommendations for Future Work 31

References 33 
Notations

Id The ductility Index

$\varepsilon_{p} \quad$ Strain at the peak on the tensile stress-strain curve

$\sigma_{p} \quad$ Stress at the peak on the tensile stress-strain curve

E Young's Modulus

$\mu \quad$ Normalized post-crack tensile strength parameter

$\omega \quad$ Yield compressive strain to cracking tensile strain ratio

$\varepsilon_{\text {or }} \quad$ Cracking tensile strain

$\sigma_{\sigma r} \quad$ cracking tensile stress

$f_{c} \cdot \quad$ Ultimate uniaxial cylinder compressive strength

$\beta_{t u} \quad$ Normalized ultimate tensile strain

$\lambda_{c u} \quad$ Normalized ultimate compressive strain

$M_{c r} \quad$ Cracking moment

$\Phi_{c r} \quad$ Cracking curvature

$\Phi_{p} \cdot$ Reduction factor

$M_{n} \quad$ Nominal moment capacity

$M_{u} \quad$ Ultimate moment capacity

$\delta \quad$ Deflection

$\mathrm{v}_{\mathrm{u}} \quad$ shear capacity (MPa)

$\rho \quad$ flexural reinforcement ratio

d effective depth of the beam

a shear span

e arch action factor $(1.0$ for $a / d>2.8$ and $2.8 d / a$ for $a / d \leq 2.8$ )

$f_{\text {spfc }}$ split cylinder strength (MPa)

$f_{\text {cuf }} \quad$ cube strength of fibre concrete and

$L_{f} \quad$ fibre length

$D_{f} \quad$ fibre diameter 
$V_{f} \quad$ volume fraction of steel fibre

$d_{f}$ bond factor $(0.5$ for round; 0.75 for crimped, and 1.0 for independent fibre

$f_{\text {fck }} \quad$ compressive strength of FRC

$d / a \quad$ beam depth to shear span ratio

$p \quad$ percentage of tension reinforcement in the $\mathrm{RC}$ beam cross section 


\section{Chapter 1}

\section{Introduction}

\subsection{Introduction}

Fiber-reinforced concrete (FRC) is a composite material made primarily from hydraulic cements, aggregates and discrete reinforcing fibers that are uniformly distributed and randomly oriented. The fibers that are randomly distributed in the matrix act as crack arrestors. Once the matrix cracks under tension, the debonding and pulling out of fibers dissipate energy leading to a substantial increase in toughness ( $\mathrm{ACl}$ Committee 544). The main areas of FRC applications are slabs-on ground, tunnel linings, and precast and prestressed concrete products. Recently, elevated slabs of steel fiberreinforced concrete (SFRC) have been successfully used where fibers provide the primary reinforcement. A wide range of FRC systems, including glass fiber-reinforced concrete (GFRC), engineered cementitious composite (ECC), slurry-infiltrated concrete (SIFCON), and fiber-reinforced ultra high strength concrete (UHSC) / ultra high performance concrete (UHPC) are in use in the industry (Chote and Barzin, 2009). Within these different fibres, the character of fibre reinforced concrete changes with varying concrete fibre materials, geometries, distribution, orientation and densities. The applications of UHSC/UHPC are limited to few market sectors due to lack of standard guidelines for design procedures.

We know that steel reinforced concrete is the most widely used structural material for construction in the world. Corrosion of reinforcing steel in concrete structures subjected to deicing salts and/or aggressive environments constitutes the major cause of their deterioration, leading to costly repair and rehabilitation and significant reduction in service life. In an effort to slow and/or prevent infrastructure deterioration, it has become a primary concern for scientists and engineers to mitigate the corrosion of - steel rebar and to look for alternative reinforcing materials to use in the place of steel to prevent corrosion altogether (Achillides and Pilakoutas, 2004). Fibre reinforced concrete with steel fibre especially UHSC/UHPC also provides a solution to this problem. Tests have shown that though the fibres located close to the surface may corrode slightly, but this superficial corrosion does not lead to the mechanical properties of the concrete (Rossi,1998). Studies also show that specimens with service level cracking in aqueous solutions (with or without chlorides) exhibit autogenous healing at the cracks (Parant, 2003; Pimienta and Chanvillard, 2004). Steel fiber-reinforced concrete (SFRC) possesses many excellent dynamic performances such as high resistance to explosion and penetration, as compared to plain concrete and even the traditionally reinforced concrete in civil and defence engineering. Findings also indicate that SFRC is a better energy absorbing and impact resisting 
material. For example, the steel fibrous concrete is six times better in receiving impact loads than the non-fibrous concrete. SFRC such as UHSC/UHPC has gained wide acceptance in a variety of applications in recent years, including industrial floors, hydraulic structures, bridge decks, airport pavements, explosion and penetration resistant structures, etc (Wang et al., 2008).

\subsection{Project Objectives}

The use of HSC and UHSCIUHPC in construction can improve strength, ductility and durability performance of infrastructures as well as can provide better service life, lower maintenance and economy. The use of UHSC/UHPC in construction is new and very limited research has been conducted to study the structural performance of such concretes. The objective of this project is to investigate the strength and deformation characteristics of high strength concrete (HSC) and fiber reinforced ultra-high strength concrete (UHSC)/ultra-high performance concrete (UHPC). The effects of various parameters such as concrete types, concrete strength (ranging from $70 \mathrm{MPa}$ to $180 \mathrm{MPa}$ ) and shear span-depth ratio $(\mathrm{a} / \mathrm{d})$ on strength characteristics of reinforced beams with shear and longitudinal reinforcements are studied.

\subsection{Project Overview}

This project is organized in six chapters. Chapter 1 gives an overview of the project. Chapter 2 provides an understanding of the high performance concrete, properties, mechanics, durability and different models that studied the behavior of steel fibre reinforced concrete including UHSC/UHPC. Chapter 3 describes the materials used in this project study and the methodologies of the experimental testing program. Chapter 4 presents the experimental results. Chapter 5 provides an analytical discussion on the findings and a comparative analysis to existing models and provisions. Chapter 6 provides the conclusions and limitations of this study and recommendations for future research. 


\section{Chapter 2}

\section{Background, Literature Review and Design Codes}

\subsection{High-Performance Concrete (HPC)}

The American Concrete Institute ( $\mathrm{ACl}$ ) defines high-performance concrete (HPC) as concrete meeting special combinations of performance and uniformity requirements that cannot always be achieved routinely when using conventional constituents and normal mixing, placing and curing practices. A highperformance concrete is something which demands much higher performance from concrete as compared to performance expected from routine concrete. Strength criteria of HPC include compressive strength, modulus of elasticity, shrinkage and creep; and durability criteria include freezethaw, scaling, abrasion and chloride permeability. Specification of HPC often requires the concrete to meet several criteria. HPC has high strength of 70-140 MPa @ 28 to 91 days (ASTM 39), high early compressive strength of 20-30 MPa @ 3-12 hours or 1-3 days (ASTM 39), and high early flexure strength of 2-4 MPa @ 3-12 hours or 1-3 days (ASTM 78) (Rossi, 2008).

\subsection{Ultra High-Performance Concrete (UHPC)}

With the demand of further higher strength, researcher has introduced Ultra High-Performance Concrete (UHPC) that produced a very dense and high compressive strength. The Association Française de Génie Civil Interim Recommendations for Ultra High Performance Fibre-Reinforced Concretes (2002) states that UHPC tends to have the following characteristics: compressive strength is greater than $150 \mathrm{MPa}$, internal fibre reinforcement to ensure non-brittle behavior, and high binder content with special aggregates. Further, UHPC tends to have very low water content (less than 0.2) and can achieve adequate rheological properties through a combination of optimized granular packing and the addition of high-range water reducing admixtures (Benjamin and Jussara, 2007). Its tensile strength is limited to around $8 \mathrm{MPa}$ and UHPCs can be very brittle. To solve these problems, it was natural for researcher to add fibres. Three major types of steel fibre-reinforced UHPCs exist today:

Type 1: UHPCs with high proportions of short fibres. The fibre content for this product is between $5 \%$ and $10 \%$ by volume, and the fibres do not exceed $6 \mathrm{~mm}$ in length. The fibres enhance the tensile strength of the concrete, but they do little to boost ductility. The material is therefore used in structures with high percentages of traditional reinforcing bars (Rossi, 2008). 
Type 2: UHPCs with intermediate proportions of long fibres. Examples include DUCTAL@ and CERACEM®, introduced in France in 1995 and 1998, respectively. Fibre contents for these products ranges between $2 \%$ and $3 \%$ by volume, and the fibre are between $13 \mathrm{~mm}$ to $20 \mathrm{~mm}$ long. The fibres enhance the tensile strength and ductility of the concrete and are intended to replace all or part of the reinforcing bars that would normally be used in prestressed or reinforced concrete elements (Rossi, 208).

Type 3: UHPCs with very high proportions of fibres of various lengths. Example of this product is CEMTECMultiscale $B$, introduced in France in 2000 . The fibre content of this product can be up to $11 \%$ by volume and the fibres can range from shorter than $1 \mathrm{~mm}$ and up to $20 \mathrm{~mm}$ long. The fibers significantly increase both the tensile strength and ductility of the concrete and can replace all the traditional reinforcing bars in an element. Just as with fiber-reinforced composites formed using an organic matrix, the matrix in a Type 3 UHPC transfers stresses between fibers and ensures certain physical and chemical properties of the material (Rossi, 2008).

\subsubsection{Ductility}

A major goal for developers of UHPCs was the full or partial replacement of traditional reinforcing bars. So it's necessary that the selected UHPC ensures a certain level of ductility in structures. Ductility at the material scale is related to behavior before localized cracking-that is, before the peak stress is developed. The ductility index $\left(I_{d}\right)$ is given by:

$$
\iota_{d}=\epsilon_{p} /\left(\sigma_{p} / E\right)
$$

where, $\varepsilon_{\rho}$ and $\sigma_{p}$ are the strain and stress at the peak on the tensile stress-strain curve, respectively, and $E$ is Young's modulus for the material (Fig.2. 1). For comparison:

- Ordinary and high-performance concretes have $I_{d}=1$;

- Type 2 UHPFRC has $l_{d}=1.5$ to 3 ;

- Type 3 UHPFRC has $l_{d}=17.5$ to 30 ; and

- Steel has $I_{d}=30$ to 60 . 


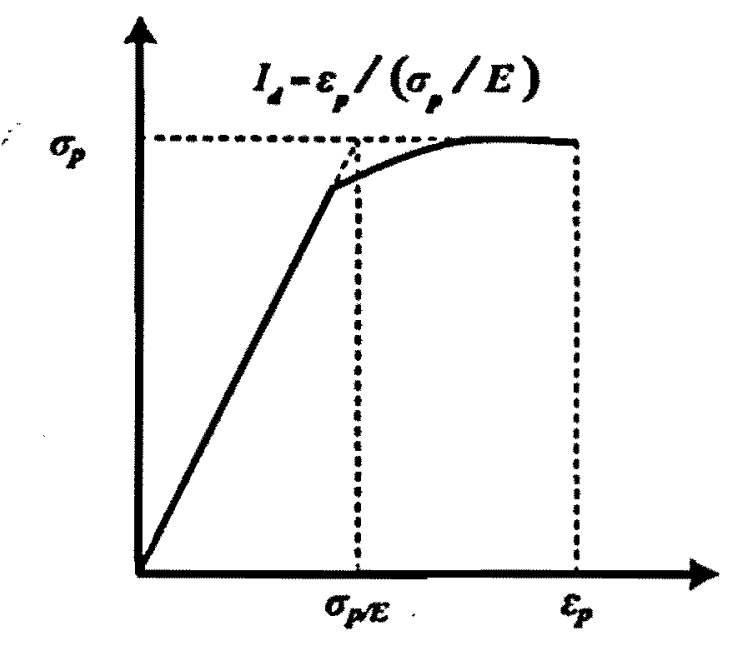

Fig. 2.1: Determination of the ductility index

Ductility at the structural scale is conditional. First, the fibers must be well oriented with respect to macrocracks that develop in the structure. Second, the structure must not be too thick because a unit width of crack opening in a deep member produces less rotation and less ductility than the same amount of crack opening in a shallower member (a purely geometrical effect). For UHPC, a reasonable maximum thickness is about three times the maximum fiber length. So, the maximum thickness for a UHPC with a maximum fiber length of $30 \mathrm{~mm}$ (1.2 in.) should be about $100 \mathrm{~mm}$ (4 in.). For prestressed structures, the fibers in the UHPC will generally be used to replace stirrups for shear behavior. Because shear cracks are more numerous and have smaller widths than flexural cracks in a reinforced concrete element of the same dimensions, the structural scale is less important.

\subsubsection{Durability}

When considering UHPCs, it's natural to be concerned about the potential for corrosion of the steel fibers. Even though fibers located close to the surface can corrode slightly, tests show that this superficial corrosion does not lead to a loss of mechanical properties (Rossi, 1998). Also, studies show that specimens with service level cracking in aqueous solutions (with and without chlorides) exhibit autogenous healing at the cracks (Parant, 2003; Pimienta and Chanvillard,2004). Type 2 UHPC with crack openings of 55 and $200 \mu \mathrm{m}$ ( 2.2 and 7.9 mil) showed $0 \%$ and $12 \%$ reductions in bearing capacity after exposure to chloride solutions. After similar exposure, Type 3 UHPC specimens showed a $14 \%$ increase in bearing capacity compared with uncracked reference specimens stored in air. The crack widths on these specimens, however, weren't measureable. For very fine cracks less than about $50 \mu \mathrm{m}$ (2 mil), autogenous healing appears to be sufficient to prevent corrosion damage. Unfortunately, no tests have been conducted on UHPC specimens subjected to simultaneous fatigue loading and chloride exposure. 


\subsection{Flexural Design of Fiber-Reinforced Concrete}

Despite the fact that FRC has been used in the construction industry for more than four decades, applications are still limited to a few market sectors. This is mainly due to the lack of standard guidelines for design procedures. To facilitate the design process, technical guidelines for FRC have been developed by RILEM (The International Union of Laboratories and Experts in Construction Materials, Systems and Structures) Committee TC162-TDF for SFRC (Vandewalle et al., 2000; Vandewalle et al., 2002; Vandewalle et al., 2003) during the past 15 years. The committee proposed a three point bending test of a notched beam specimen for material characterization. The elastically equivalent flexural strength at specific crack mount opening displacement (CMOD) is empirically related to the tensile stress-strain model. The compression response is described by a parabolic-rectangular stress-strain model. The strain compatibility analysis of a layered beam cross section is required to determine the ultimate moment capacity. Similar to the RILEM, German guidelines for design of flexural members use the strain compatibility analysis to determine the moment capacity (Teutsch, 2004). In the UK (Barr and Lee, 2004), the practice of FRC traditionally followed the Japanese Standard JCI-SF4 (JSCE-SF4); however, it has recently shifted toward the RILEM design methodology. The Italian guideline is also based on load-deflection curves deduced from flexural or direct tension tests (di Prisco et al., 2004). The current U.S. design guidelines for flexural members are based on empirical equations (Swamy et al., 1975; Fischer, 2004). Particular types of fibers and natures of concrete were not specified in the guidelines. Henager and Doherty (1976) proposed a tensile stress block for SFRC that is comparable with the ultimate strength design of $\mathrm{ACl} 318-05$.

In this paper a design methodology for strain softening FRC is discussed for ultimate strength and design for serviceability. The design procedures are based on theoretical derivations of Soranakom and Mobasher (Soranakom and Mobasher, 2007; 2008), in addition to ACI 318-05 and RILEM TC 162-TDF (Vandewalle et al., 2003).

\subsubsection{Strain-Softening FRC Model}

Tensile and compressive response of strain-softening FRC such as steel and polymeric fiber-reinforced concrete (SFRC and PFRC) can be simplified to idealized stress-strain models as shown in Fig. 2.2 (a) and (b). In these materials, the contribution of fibers is mostly apparent in the post-peak tensile region, where the response is described by a decaying stress-strain relationship. It is possible, however, to assume an average constant post-crack tensile strength $\sigma_{\rho}$ for the softening response, which can be correlated to the fiber volume fraction and their bond characteristics (Swamy et al., 1975; Fischer, 2004; Henager and Doherty, 1976). 


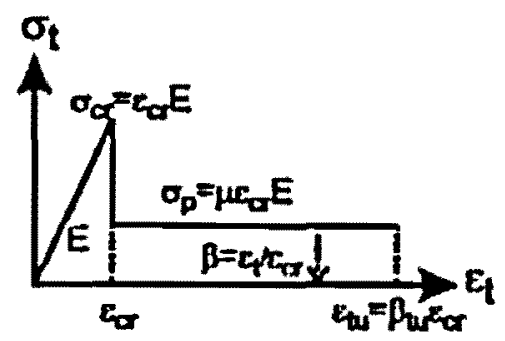

(a)

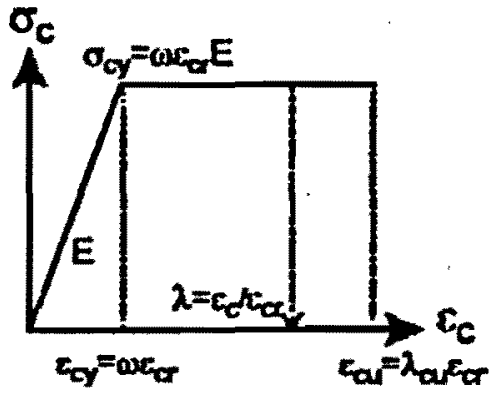

(b)

Fig.2.2: Idealized material models for strain-softening fiber-reinforced concrete: (a) tension model; and (b) compression model.

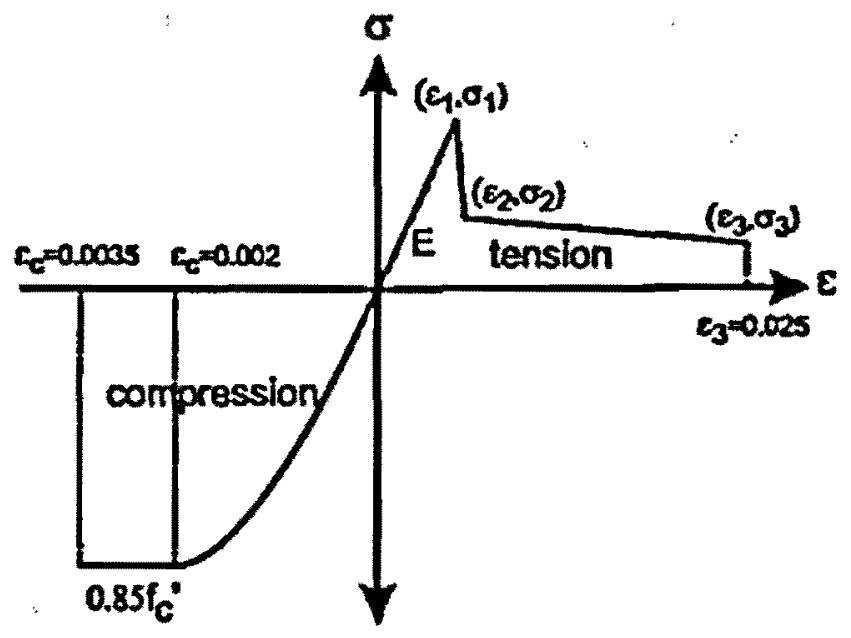

Fig. 2.3: RILEM material model for steel fiber-reinforced concrete.

The following assumptions are made in the development of the material models:

- Young's modulus $E$ for compression and tension are equal;

- Tension model in fig. 2.2(a) consists of a linear stress-strain response up to the cracking tensile strain $\varepsilon_{c r}$ followed by a constant post-crack tensile strength $\sigma_{p}=\mu \varepsilon_{c r}$ with a parameter $\mu(0 \leq \mu \leq 1)$, representing normalized post-crack tensile strength parameter. Here $\sigma_{p}$ represents the post-crack strength as a fraction of the cracking tensile strength $\sigma_{\mathrm{cr}}=E \varepsilon_{\mathrm{cr}}$; and

- The compression model is defined by an elastic perfectly plastic model (Fig. 1(b)) using a yield compressive strain $\varepsilon_{\mathrm{cy}}=\omega \varepsilon_{\alpha}$ with a parameter $\omega(\omega \geq 1)$ representing the yield compressive strain to cracking tensile strain ratio.

A study of material parameters (Soranakom and Mobasher, 2007) reveals that the ultimate moment capacity of FRC is significantly affected by $\mu$ while less sensitive to $\omega$. To minimize the number of material parameters, the tensile strength and Young's modulus are assumed to be marginally affected 
by fiber type and content and conservatively estimated by the relationship governing normal concrete using $A C I$ 318-05 Sections 11.2 and 8.5.1, respectively

$$
\begin{aligned}
& \sigma_{c r}=E \varepsilon_{c r}=0.56 \sqrt{f_{c}^{\prime}}(\mathrm{MPa}) \\
& E=4733 \sqrt{f_{c}^{\prime}}(\mathrm{MPa})
\end{aligned}
$$

where $f_{c}^{\prime}$ is the ultimate uniaxial cylinder compressive strength (MPa). First crack tensile strain for FRC can be calculated assuming Hooke's law as

$$
\varepsilon_{c r}=\frac{\sigma_{c r}}{\varepsilon}=\frac{0.56 \sqrt{f_{c}^{\prime}}}{4733 \sqrt{f_{c}^{\prime}}}=118 \text { microstrain }
$$

According to the RILEM model (Vandewalle et al., 2003) shown in Fig. 2.3, the ultimate tensile strain $\varepsilon_{3}$ is defined as 0.025 . The ultimate compressive strain $\varepsilon_{c u}$ is limited to 0.0035 , which is the lower bound value of typical SFRC (Swamy and Al-Ta'an, 1981; Hassoun and Sahebjam, 1985), and the yield compressive strength for FRC is adopted as

$$
\sigma_{c u}=0.85 f_{c}^{\prime}(\mathrm{MPa})
$$

The two normalized parameters used in the material models (Fig. 2(a) and (b)) are summarized as follows

$$
\begin{aligned}
& \mu=\frac{\sigma_{p}}{E \varepsilon_{c r}} \\
& (2.5) \\
& \omega=\frac{\varepsilon_{c y}}{\varepsilon_{c r}}=\frac{\sigma_{c y}}{E \epsilon_{c r}}=\frac{\sigma_{c y}}{\sigma_{c r}}=1.52 \sqrt{f_{c}^{\prime}}(\mathrm{MPa})
\end{aligned}
$$

Equation (2.6) implies that the normalized yield compressive strain $\omega$ is also a compressive-to-tensile strength ratio; thus, these terms can be used interchangeably. For typical $f_{c}^{\prime}$ between 20 and $65 \mathrm{MPa}, \omega$ varies between 6.8 and 12.8. The tensile and compressive responses terminate at the normalized ultimate tensile strain $\beta_{t u}$ and compressive strain $\lambda_{c u}$, respectively

$$
\begin{aligned}
& \beta_{t u}=\frac{\varepsilon_{t u}}{\varepsilon_{c r}}=212 \\
& \lambda_{c u}=\frac{\varepsilon_{c u}}{\varepsilon_{c r}}=30
\end{aligned}
$$

Note that the terms $\beta$ and $\lambda$ without subscript refer to normalized tensile strain $\left(\varepsilon_{d} / \varepsilon_{c r}\right)$ and compressive strain $\left(\varepsilon_{d} / \varepsilon_{\mathrm{cr}}\right)$, respectively, and are functions of imposed curvature on a section. 


\subsubsection{Moment Curvature Response}

For a rectangular section, the derivations for neutral axis depth ratio $k$, normalized moment $m$, and normalized curvature $\varphi$ are described in an earlier publication (Soranakom and Mobasher, 2007). Figure 3 shows three ranges of applied top compressive strain $0 \leq \varepsilon_{c} \leq \varepsilon_{c r}, \varepsilon_{c r} \leq \varepsilon_{c} \leq \varepsilon_{c y}$ and $\varepsilon_{c y} \leq \varepsilon_{c} \leq \varepsilon_{c u}$ or in dimensionless form, $0 \leq \lambda \leq 1,1 \leq \lambda \leq \omega$ and $\omega \leq \lambda \leq \lambda_{c u}$.

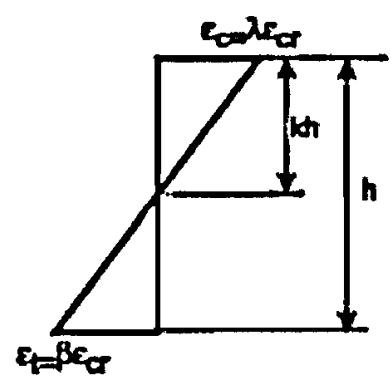

(a)

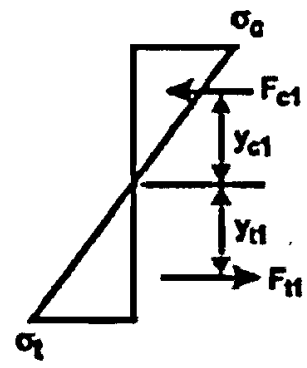

(a)

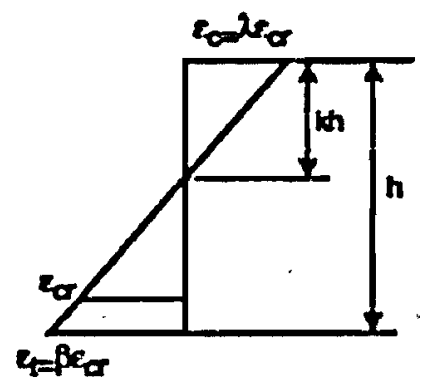

(b)

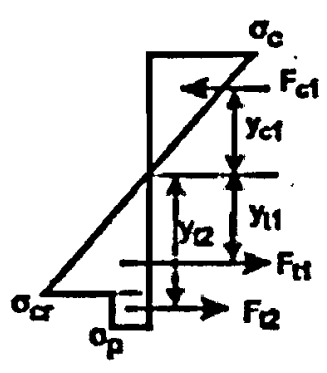

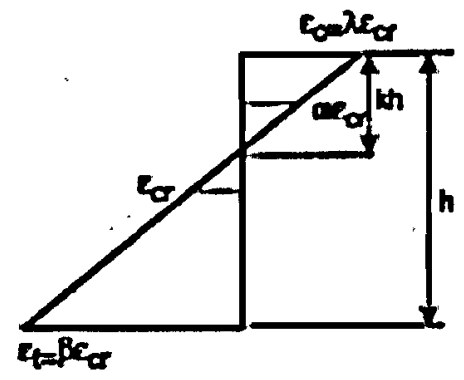

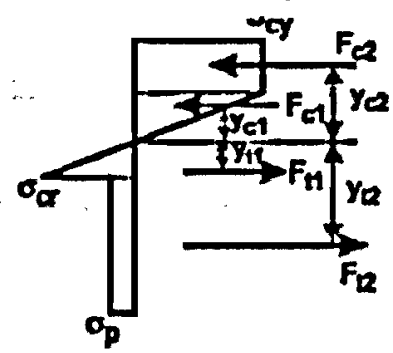

(c)

Fig. 2.4: Stress-strain diagram at three ranges of normalized top compressive strain $\lambda$ : (a) elastic for compression and tension $(0<\lambda \leq 1)$; (b) elastic for compression but nonlinear for tension $(1<\lambda \leq \omega)$; and (c) plastic for compression and nonlinear for tension $(\lambda>\omega)$.

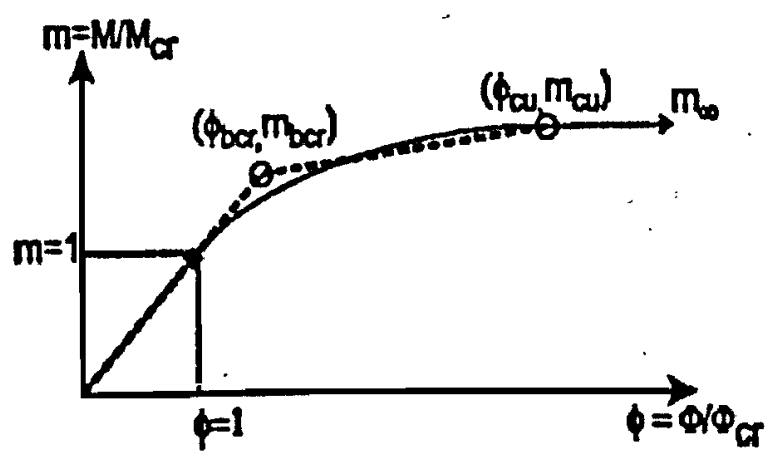

Fig. 2.5: Normalized moment-curvature response for strain-softening deflection-hardening material and its simplified bilinear model. 
The location of neutral axis parameter $k$ can be derived by solving the equilibrium of internal forces. The moment can be computed from taking the force about the neutral axis, while the curvature is obtained by dividing top compressive strain with the depth of neutral axis. The corresponding closed form solutions for normalized neutral axis, moment, and curvature $(k, m, \varphi)$ are presented in Table 2.1.

Table 2.1 Neutral axis depth ratio and normalized moment curvature expression for three ranges of applied normalized top compressive strain $A$

\begin{tabular}{c|c|c|}
\hline Range & $k$ & $m$ \\
\hline $0 \leq \lambda \leq 1$ & $\frac{1}{2}$ & $\frac{\lambda}{2 k}$ \\
\hline $1 \leq \lambda \leq 0$ & $\frac{2 \mu \lambda}{\lambda^{2}+2 \mu(\lambda+1)-1}$ & $\frac{\left(2 \lambda^{3}+3 \mu \lambda^{2}-3 \mu+2\right) k^{2}}{\lambda^{2}}-$ \\
\hline $\begin{array}{c}\omega \leq \lambda \leq \\
\lambda_{b=1}\end{array}$ & $\frac{3 \mu(2 k-1)}{-\omega^{2}+2 \lambda(\omega+\mu)+2 \mu-1}$ & $\frac{2 \mu \lambda}{2 k}$ \\
\hline
\end{tabular}

Using these expressions, the moment $M$ and curvature $\Phi$ represented in terms of their first cracking values $\left(M_{c r}\right.$ and $\left.\Phi_{c r}\right)$ are defined as

$$
\begin{aligned}
& M=m M_{c r} ; \quad M_{c r}=\frac{\sigma_{c r}}{6} b h^{2} \\
& \varphi=\theta \varphi_{c r} ; \quad \varphi_{c r}=2 \varepsilon_{c r} / h
\end{aligned}
$$

where $b$ and $h$ are width and height of beam, respectively. The moment capacity at ultimate Compressive strain $\left(\lambda=\lambda_{c u}\right)$ is very well approximated by the limit case of $(\lambda=\infty)$. Using the expression for $k$ in range 3 of Table 1 , one obtains the neutral axis parameter at infinity $k$. (Soranakom and Mobasher, 2007).

$$
k_{\infty}=\frac{\mu}{\omega+\mu}
$$

By substituting $k=k_{m}$ and $\lambda=\infty$ in the expression for $m$ in range 3 of Table 1 , the ultimate moment capacity $m_{*}$ is also obtained

$$
m_{\infty}=\frac{3 \omega \mu}{\omega+\mu}
$$




\subsubsection{Ultimate Moment Capacity}

Load and resistance factor design (LRFD) is based on the reduced nominal moment capacity $\Phi_{p} M_{n}$, exceeding the ultimate factored moment $M_{\nu}$ that is determined by linear elastic analysis and load coefficients in accordance to $\mathrm{ACl}$ 318-05 Section 9.2. The reduction factor $\Phi_{\rho}$ addresses the uncertainty of using post-crack tensile strength in predicting ultimate moment capacity. Based on the statistical analysis of limited test data (Soranakom and Mobasher, 2008), a value $\Phi_{p}=0.7$ was used in this study. The nominal moment capacity $M_{n}$ can be obtained by using Eq. (2.13) and (2.14) with the reduction factor

$$
\theta_{p} M_{n}=\theta_{p} M_{\infty} M_{c r}=3 \omega \mu \theta_{p} M_{c r} /(\omega+\mu) \geq M_{u}
$$

Alternatively, the nominal moment capacity can be expressed as a function of post-crack tensile strength $\mu$ and compressive strength $f_{c}^{\prime}$ by substituting Eq. (2.6) in (2.13).

$$
\varphi_{p} M_{n}=\left[\frac{6 \mu \sqrt{ } f_{c}^{\prime}}{\xi \mu+2 \sqrt{f_{c}^{\prime}}}\right] \varphi_{p} M_{c r}
$$

$\left(\xi=1.32\right.$ for $f_{c}^{\prime}$ in $\left.\mathrm{MPa}\right)$

The post-crack tensile strength necessary to carry the $M_{u}$ can be obtained from Eq. (2.14) as

$$
\mu=\frac{2 M_{u} \sqrt{f_{c}^{\prime}}}{6 \theta_{p} M_{c r} \sqrt{f_{c}^{\prime}-\xi M_{u}}}
$$

\subsubsection{Deflection Calculation for Serviceability}

The present approach can be used to compute the deflections by integration of the curvature along the beam length. Geometric relationship between curvature and deflection has been derived by Ghali and Favre (Ghali and Favre, 1986). The curvature distribution along the length can be arbitrary; however, a parabolic or linear shape gives accurate results, whereas other shapes result in approximate values. The sign convention for curvature is the same as the convention used for moments. Two typical cases of a simple beam are presented in Fig. 2.6. 


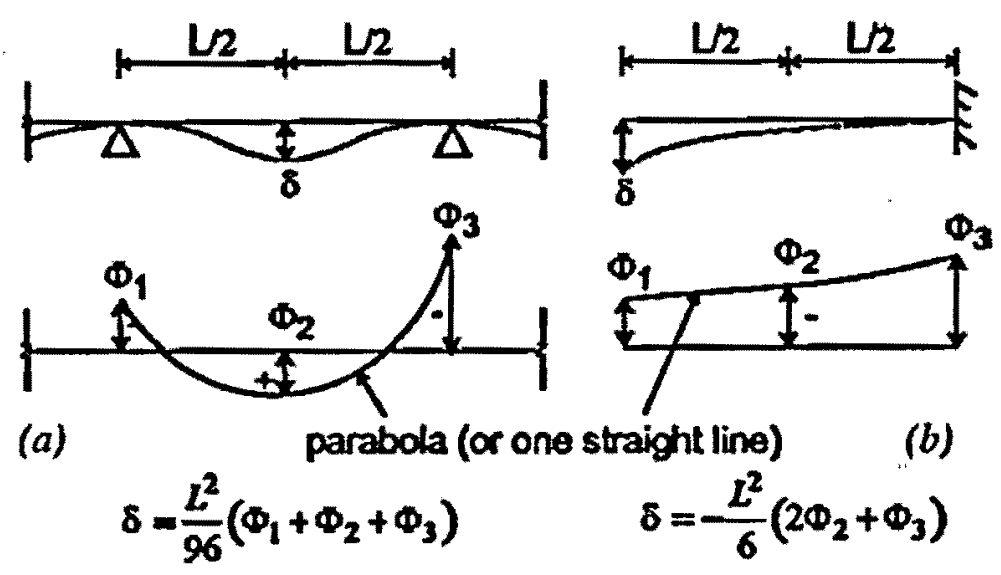

Fig. 2.6: Geometric relationship between curvature and deflection.

The midspan deflection $\delta$ of a simple or continuous beam can be computed by

$$
\delta=\frac{L^{2}}{96}\left(\varphi_{1}+\varphi_{2}+\varphi_{3}\right)
$$

The deflection of a cantilever beam can be computed by

$$
\delta=\frac{L^{2}}{6}\left(2 \varphi_{2}+\varphi_{3}\right)
$$

where, $\mathrm{L}$ is the span length, and $\varphi_{1}, \varphi_{2}$, and $\varphi_{3}$ are the curvature at left end, centre and right end respectively.

\subsection{Shear Strength of High-Performance FRC}

Shear failure in reinforced concrete beams is generally catastrophic because of the brittle behaviour of plain concrete. This type of failure can be prevented by using appropriate reinforcement if the direction of load is known. If the loading direction is not known (such as earthquake) then shear failure remains a distinct possibility in RC beam. Shear failure occurs when the principal stress exceeds the tensile strength of the concrete and the principal crack propagate diagonally, by producing diagonal tension or shear compression failure modes, depending on the ratio between the shear span and the effective depth of the beams (Campione et al.,2006). If the shear strength and shear toughness of concrete can be improved, the shear failure of RC beam could be avoided and the behaviour of concrete could be changed from brittle to ductile. In both failure modes the addition of fibres in a suitable percentage and geometry produces a significant increase in shear strength and in some cases can also change the failure mode shear to flexure. In these cases, fibres can partially substitute transverse stirrups and have the same effect in terms of shear strength (Campione et al., 2006). It is known that fibre reinforcement is one of the most effective means of enhancing the fracture toughness in all the three modes of failure 
(opening, sliding and tearing). Research has clearly established the potential use of fibre reinforcement for increasing the shear capacity of RC beams (Calixto et al., 2002; Dupont and Vandewalle, 2003).

Following sections will discuss different models in determining the shear strength of RC beams with stirrups containing fibre reinforcement

\subsubsection{Narayan and Darwish (1987) Model}

Narayan and Darwish proposed an equation for calculating the contribution of concrete and fibre to the shear capacity of RC beam, and the contribution of stirrups is calculated on the basis of the design codes. He proposed that the shear capacity of steel-fiber-reinforced RC beams

$$
v_{u}=e\left[0.24 f_{s p f c}+80 \rho\left(\frac{d}{a}\right)\right]+v_{b}
$$

where,

$v_{u}=$ shear capacity $(\mathrm{MPa})$

$\rho=$ flexural reinforcement ratio

$d=$ effective depth of the beam

$a=$ shear span

$e=$ arch action factor $(1.0$ for $a / d>2.8$ and $2.8 d / a$ for $a / d \leq 2.8$ )

$f_{\text {spfc }}=$ split cylinder strength (MPa)

$$
f_{s p f c}=\frac{f_{c u f}}{(20-\sqrt{F})}+0.7+\sqrt{F}
$$

where,

$f_{\text {cuf }}=$ cube strength of fibre concrete and

$F=\left(L_{f} / D_{f}\right) V_{f} d_{f}$, in which,

$L_{f}=$ fibre length

$D_{f}=$ fibre diameter

$V_{f}=$ volume fraction of steel fibre

$d_{f}=$ bond factor ( 0.5 for round, 0.75 for crimped, and 1.0 for independent fibre)

Again, " $v_{b}=0.41 \tau F$

Where, $T=$ average fibre-matrix interfacial bond stress (assumed to be $4.15 \mathrm{MPa}$ )

\subsubsection{RILEM TC 162-TDF 2000 Model}

This approach is based on Eurocode 2 (CEN 1992). The contribution of fibres to shear capacity is independently computed using toughness enhancement in flexure by the fibres. The shear capacity of beam is given by 


$$
V=V_{c}+V_{w}+V_{f}
$$

where,

$V=$ shear capacity of the member, $V_{c}=$ contribution of concrete, $V_{w}=$ contribution of stirrups, and $\quad V_{f}=$ contribution of fibre. $V_{c}$ and $V_{w}$ are calculated according to Eurocode 2.

again, $V_{c}=\left[0.12 k \sqrt[3]{\left(100 \rho_{1} f_{f c k}\right)}+0.15 \sigma_{c p}\right] b d$

where,

$k=1+\sqrt{200 / d}$ (d in $\mathrm{mm})$

$\sigma_{c p}=N_{s d} / A_{c}\left(\mathrm{~N}_{s d}\right.$ is the longitudinal force in the section due to loading in $\mathrm{MPa}$ and $\mathrm{A}_{c}$ is

the cross sectional area of the beam)

$\rho_{1}=A_{s} / b d, A_{s}$ is area of tension reinforcement in the beam section

$f_{\text {fck }}=$ compressive strength of FRC

again $\quad V_{f}=0.7 k_{f} k_{l} \tau_{f d} b d$

where,

$k_{f}=1+n\left(h_{f} / b_{w}\right) /\left(h_{f} / d\right)$, (for T-section, $\left.n=\left(b_{f}-b_{w}\right) / h_{f} \leq 3\right)$

$k_{l}=(1600-d) / 1000$, (d in $\mathrm{mm}$ and $\left.k_{l} \geq 1.0\right)$

$h_{f}=$ height of flanges $(\mathrm{mm}), b_{f}=$ width of flanges $(\mathrm{mm}), b_{w}=$ width of web $(\mathrm{mm})$

$\tau_{f d}=0.12 f_{e q 3} \quad\left(f_{\text {eq. } 3}=\right.$ equivalent flexural tensile strength derived using the load deflection curve of notched-beam FRC specimens under three-point loading (RILEM TC 162-TDF 2000).

There are two deficiencies in the approach taken by RILEM. First, because FRCs behave differently in shear than in flexure (Mirsayah and Banthia, 2002), the use of flexure properties to determine the shear response makes limited sense. Second, since fibre is integral part of any FRC, their shear response should not be separated from the plain concrete.

\subsubsection{Majdzadeh et al. (2005) Model}

Majdzadeh et al. proposed a new equation where the shear contribution of concrete, fibres and stirrups were taken into consideration. For contribution of the concrete, a modified Eurocode 2 (CEN 1991) expression was used and for contribution of fibre, an equation based on the results of direct shear tests on FRC specimens was used. To account for contribution of stirrups, the expression in Eurocode 2 was used. Finally the proposed equation was

$$
V_{u}=\left[0.173 \sqrt[3]{(3 d / a)} \sqrt[3]{\left(100 \rho f_{c}^{\prime}\right)}(1+\sqrt[2]{(200 / d)})+K \tau_{f, F R c}\right] b d+V_{w}
$$

Where, 
$d / a=$ beam depth to shear span ratio

$\rho=$ percentage of tension reinforcement in the $\mathrm{RC}$ beam cross section

$1+(200 / d)^{1 / 2}=$ size effect in the shear strength of RC beam

$K=0.216$ for steel fibre (limited to maximum $1 \%$ volume fraction) and 0.290 for synthetic fibres

$\tau_{f, F R C}=\tau_{F R C}-\tau_{\text {plain }}$, shear strength of FRC and plain concrete respectively and determined by direct shear test.

and $\quad V_{w}=\left(A_{s w} / S\right) 0.9 d F_{y}$

Where, $A_{s w}$ is the cross sectional area of the shear reinforcement $\left(\mathrm{mm}^{2}\right), S$ is spacing between the shear reinforcement measured along the longitudinal axis $(\mathrm{mm}), F$ is the yield strength of shear reinforcement $(\mathrm{MPa})$.

\subsubsection{Summary}

The use of high strength concrete (HSC) and UHSC/UHPC in construction can improve strength, ductility and durability performance of infrastructures as well as can provide better service life, lower maintenance and economy. The use of UHSC/UHPC in construction is new and very limited research has been conducted to study the structural performance of such concretes. There are many theoretical models available that address the shear capacity of fiber reinforced concrete but little research has been conducted to apply and modify these models to determine strength properties of UHSC/UHPC based reinforced beams. 


\section{Chapter 3}

\section{Experimental Program}

\subsection{Materials}

The following sections discuss the materials and their corresponding properties used in this study. Three UHSC/UHPC mixes namely Ductal1, Ductal 2 and Ryerson concrete and one HSC namely King concrete were used. Ductal1 was produced to provide a compressive strength of above 150 $\mathrm{MPa}$ and Ductal 2 was produced to provide compressive strength of above $170 \mathrm{MPa}$. Ryerson concrete was developed at Ryerson with compressive strength of about $140 \mathrm{MPa}$. The general mix proportions are provided in Table 3.1 for Ductal1 and Ductal2.

Table 3.1: Ductal1 and Ductal2 Mix Proportions

\begin{tabular}{lcccc}
\hline Mix & Ductal Premix & Water & Admixture & Fibres \\
\hline Ductal1 & 2194 & 155 & 30 & 156 \\
Ductal2 & 2194 & 139.5 & 27 & 156 \\
\hline all values in $\mathrm{kg} / \mathrm{m}$ & & &
\end{tabular}

all values in $\mathrm{kg} / \mathrm{m}$

Both Ductal8 mixes were self-consolidating. Ductal1 specimens reached their maximum strength after 21 days from casting whereas Ductal 2 specimens their maximum strength after 35 days from casting. The Ductal $\circledast$ compressive strength development is shown in Figure 3.1. The compressive strength attained for Ductal1 specimens was $150 \mathrm{MPa}$ and the compressive strength attained for Ductal2 specimens was $175 \mathrm{MPa}$. The control cylinders had a standard deviation of $6.19 \mathrm{MPa}$ and $8.77 \mathrm{MPa}$ and a coefficient of variation of $4.1 \%$ and $5.0 \%$ for Ductal 1 and Ductal2 cylinders respectively. 


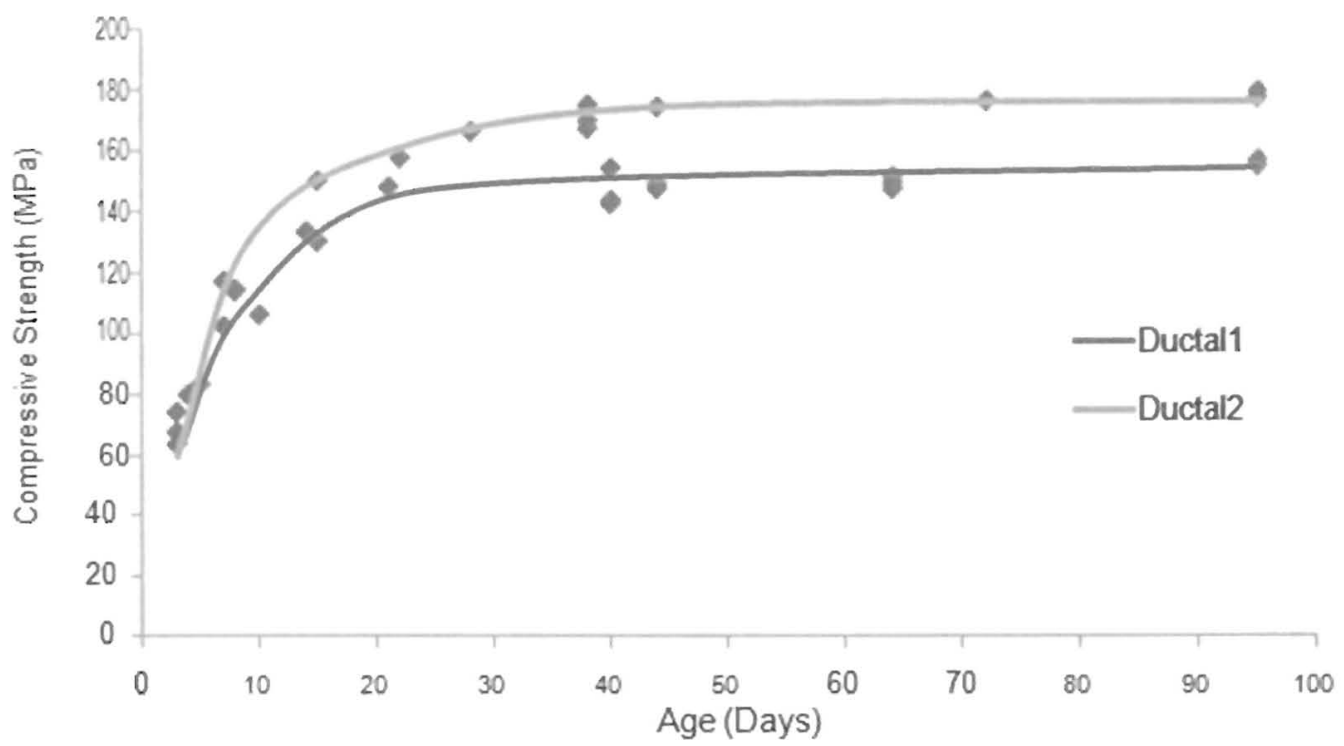

Figure 3.1: Compressive Strengtn Development of Ductal $\circledast$

The mix developed at Ryerson University was designed to have a compressive strength between 115-135 MPa. Ryerson Concrete is a self-consolidating IIHPC produced from GU Lafarge Portland Cernent, silica fume (Microsilica Grade 971-U), F-110 Silica Sand Natural Grain, steel fibres (Straight fibres, length $=13 \mathrm{~mm}$, diameter $=0.2 \mathrm{~mm}$.), superplasticizer (ADVA® Cast 575), and water Since the Ryerson Concrete was supposed to provide compressive strengths between 115-130 MPa, the specimens needed to be tested between 23-24 days after casting when they attained an average compressive strength of $128.6 \mathrm{MPa}$. It was essential to test the specimens within that time frame or consequently the specimens would continue to gain strength and exceed the desired compressive strength range. The compressive strength development of Ryerson Concrete is shown in Figure 3.2. The compressive strength attained for Ryerson Concrete appeared to reach a maximum value of 152 MPa after 75 days. The control cylinders had a standard deviation of $5.62 \mathrm{MPa}$ and a coefficient of variation of $4.4 \%$. 


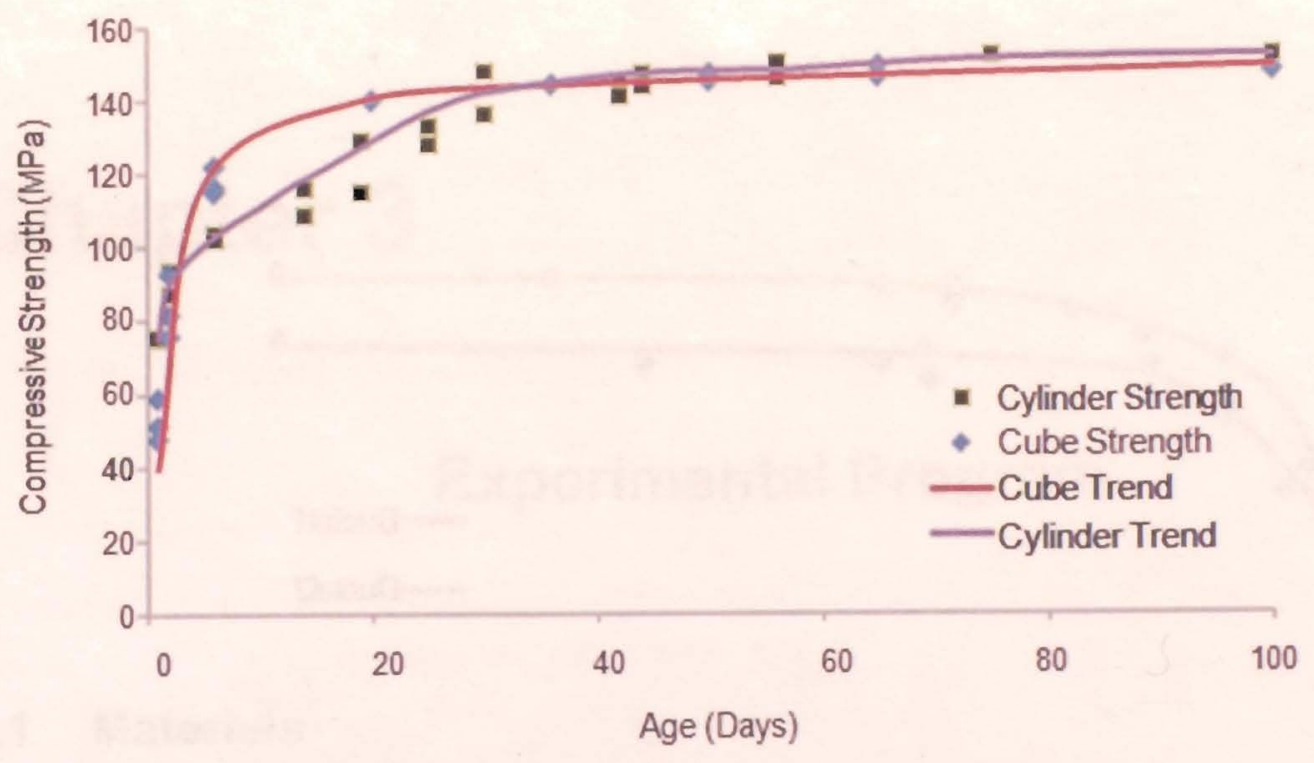

Figure 3.2: Ryerson Concrete Compressive Strength Development

The mix developed from King concrete was designed to have a compressive strength between 60-70 MPa. The compressive strength of king concrete is shown in Figure 3.3.

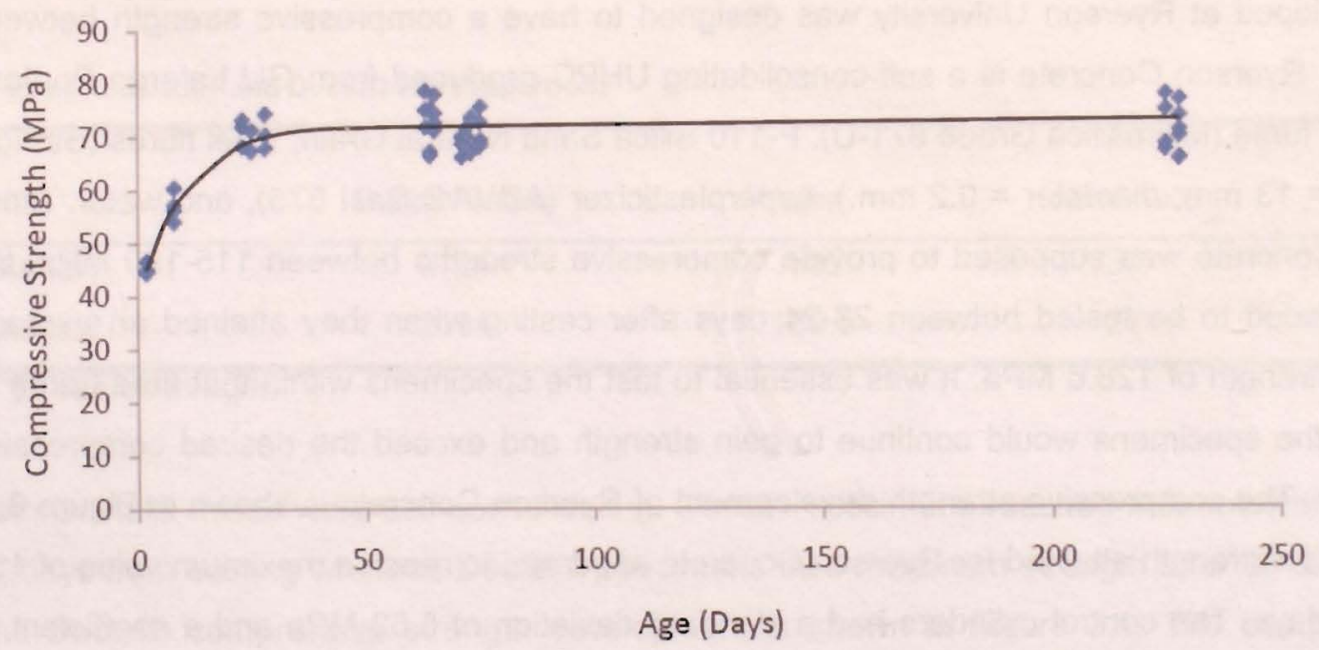

Figure 3.3: King Concrete Compressive Strength Development 


\subsection{Geometry of Test Specimens}

Two types of beam geometry (Type A and Type B) with longitudinal and shear reinforcements were tested in this study. The longitudinal and shear reinforcements for each types of beams were kept constant, The beam geometry, shear span to depth ratio and concrete types (representing varying concrete strength from $70 \mathrm{MPa}$ to $175 \mathrm{MPa}$ ) were the variable parameter in the tests The dimensions and reinforcement details of the specimens from both Type $A$ and Type $B$ are shown in Figures 3.4 and 3.5 .
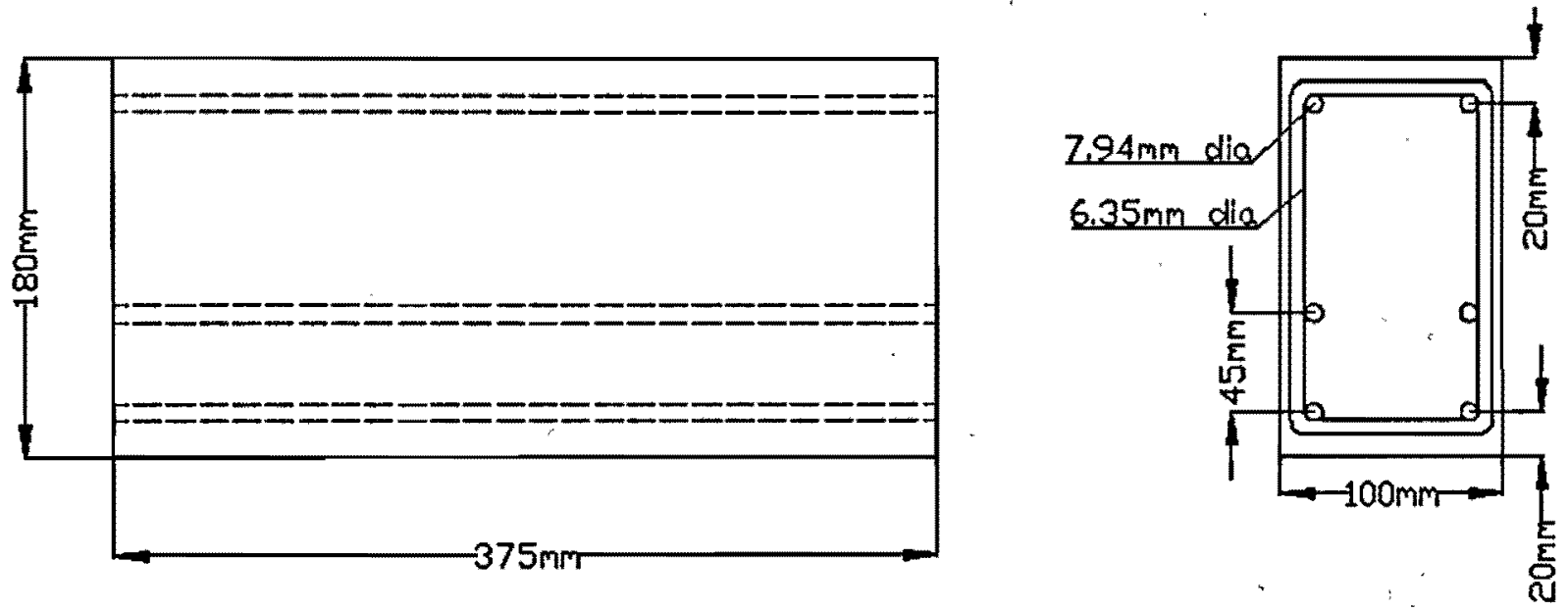

Type A Beam

Figure 3.4: Geometry of Type A specimen.
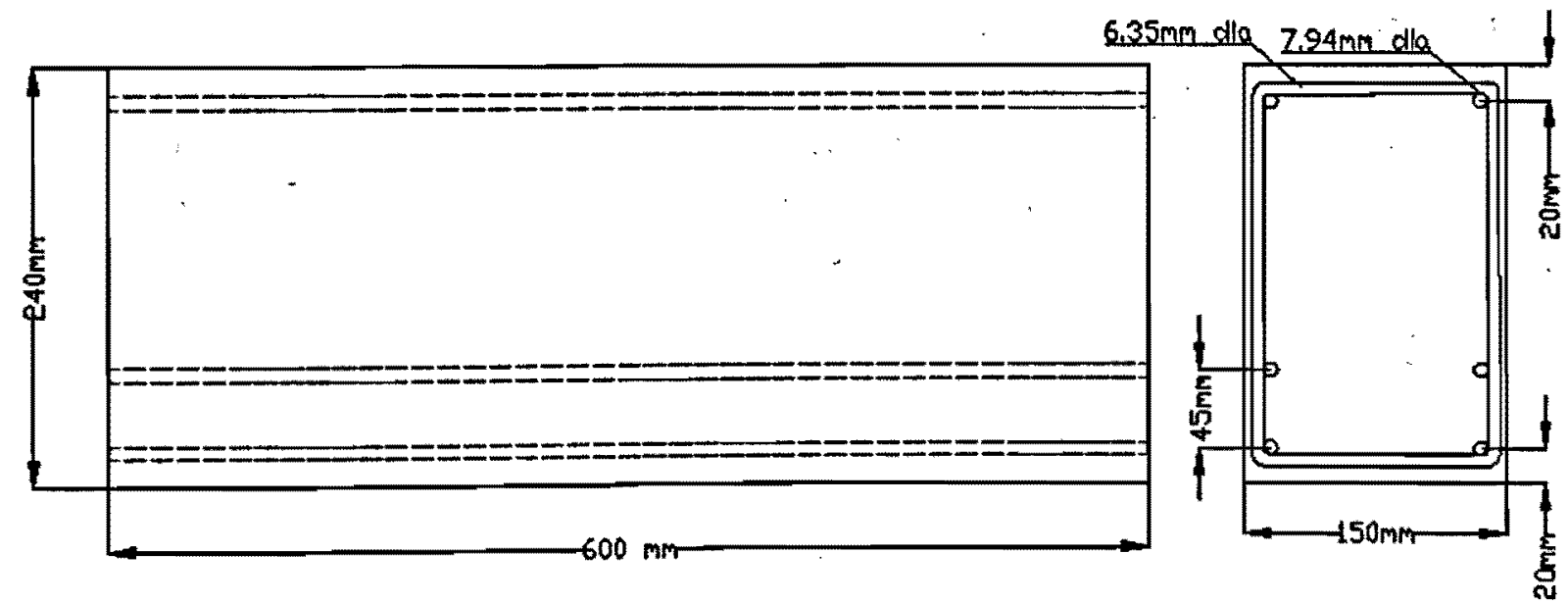

Type B Beam

Figure 3.5: Geometry of Type B specimen. 


\subsection{Test Variables}

In this project, 56 Type A and 43 Type B beams were tested. The distributions of specimen for different tests are shown in table 3.2. Table 3.2 also shows the compressive strength and geometrical "parameters of the test specimens.

Table 3.2: Distribution of beams for the tests of type A and type B

\begin{tabular}{|l|l|c|c|c|c|c|}
\hline \multirow{2}{*}{ Type of concrete beam } & \multicolumn{5}{|c|}{ \# of Beam Tested } & \multirow{2}{*}{ Total } \\
\cline { 2 - 7 } & Span(mm), a/d & Ductal1 & Ductal2 & Ryerson & King & \\
\hline $\begin{array}{l}\text { Concrete strength } \\
\left(f_{c}\right), \mathrm{MPa}\end{array}$ & & 150 & 175 & 135 & 70 & \\
\hline Type A & span=300 & 14 & 14 & 14 & 14 & 56 \\
\hline \multirow{2}{*}{\begin{tabular}{l} 
Type B \\
\multirow{3}{*}{$\begin{array}{l}\text { a/d:shear span to } \\
\text { Depth ratio }\end{array}$}
\end{tabular}} & $\mathrm{span}=520$ & 4 & 4 & 4 & 4 & 16 \\
\cline { 2 - 8 } & $\mathrm{a} / \mathrm{d}=1.0$ & 3 & 3 & 3 & 3 & 12 \\
\cline { 2 - 8 } & $\mathrm{a} / \mathrm{d}=1.4$ & 3 & 3 & 3 & 3 & 12 \\
\cline { 2 - 8 } & $\mathrm{a} / \mathrm{d}=1.74$ & 3 & 0 & 0 & 0 & 3 \\
\hline
\end{tabular}

\subsection{Testing}

The specimens were tested in a testing set-up with a maximum load carrying capacity of $1400 \mathrm{KN}$. The load was applied through a single-ended actuator to the center of each specimen, which was supported on two steel rollers covering the entire width of the specimen. A LVDT was placed under the beam along the loading point to measure the deflection. Fig. 3.6 shows the test setup. A computer aided data acquisition system was used to monitor the load-central deflection response throughout loading history until failure of the specimens. Suring testing, over all behaviour including cracking, cracking propagation and failure models of the beams were observed. 


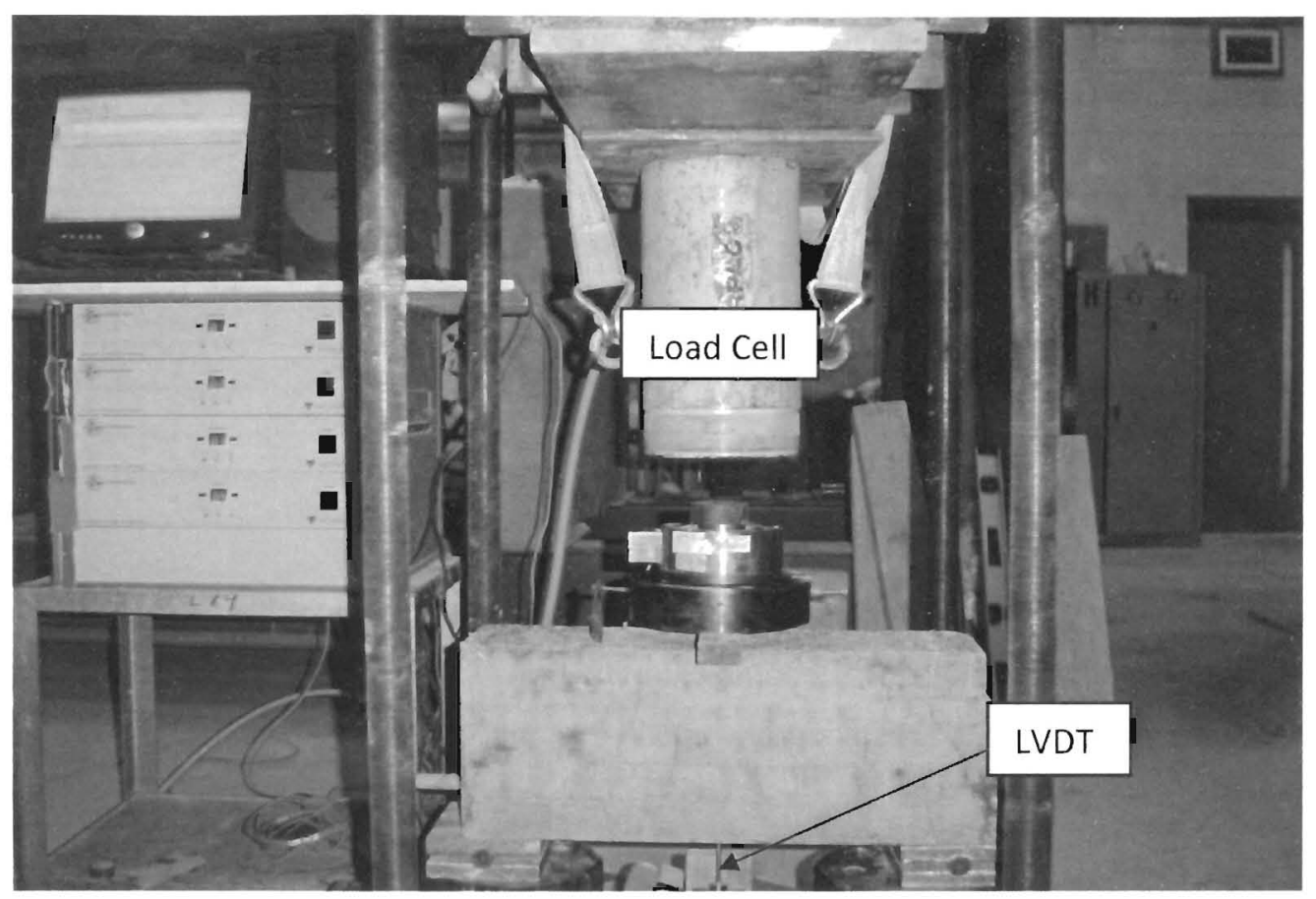

Fig. 3.6: Test setup picture 


\section{Chapter 4}

\section{Experimental Results}

\subsection{General}

This chapter presents the experimental results from the test conducted in this project. The project was focused to determine the behaviour of beams with HSC and UHSC/UHPC concrete under point load. The next chapter will analyze the results presented in this chapter.

\subsection{Test Results}

Following tables summarise the test results obtained from Type $A$ and Type $B$ beam test $s$ under point load. Four concrete mixes (one HSC with aggregate and no fiber namely "King"; three UHSC/UHPC namely Ductal 1, Ductal 2 and Ryerson with no coarse aggregate and steel fiber) were considered for these tests. Table 4.1 summarises the maximum load and maximum deflection for Type A beam. Table 4.2 summarises the maximum load and maximum deflection for Type $B$ beam. Tables $4.3,4.4$, and 4.5 summarises the maximum load and maximum deflection for Type $B$ beam with different a/d ratio.

Table 4.1: Max Load-Deflection Type A beam

\begin{tabular}{|c|c|c|c|c|c|c|c|c|c|c|c|}
\hline Type of & Max & Max & Type of & Max & Max & Type of & Max & Max & Type of & Max & Max \\
\hline Mix & Load & Deflection & Mix & Load & Deflection & Mix & load & Deflection & Mix & Load & Deflection \\
\hline & (KN) & $(\mathrm{mm})$ & & (KN) & $(\mathrm{mm})$ & & (KN) & $(\mathrm{mm})$ & & (KN) & $(\mathrm{mm})$ \\
\hline Ductal1-1 & 323 & 2.08 & Ductal2-1 & 359 & 2.15 & Ryerson-1 & 479 & 2.11 & King-1 & 135 & 0.09 \\
\hline Ductal1-2t & 412 & 2.25 & Ductal2-2 & 371 & 2.47 & Ryerson-2 & 308 & 1.79 & King-2 & 88 & 0.09 \\
\hline Ductal1-3 & 406 & 2.5 & Ductal2-3 & 383 & 1.9 & Ryerson-3 & 295 & 1.72 & King-3 & 127 & 0.34 \\
\hline Ductal1-4 & 511 & 1.96 & Ductal2-4 & 418 & 1.6 & Ryerson-4 & 266 & 1.53 & King-4 & 130 & 0.18 \\
\hline Ductal1-5 & 303 & 2.69 & Ductal2-5 & 341 & 1.55 & Ryerson-5 & 286 & 1.71 & King-5 & 120 & 0.09 \\
\hline Ductal 1-6 & 402 & 2.07 & Ductal2-6 & 437 & 1.72 & Ryerson-6 & 283 & 2.11 & King-6 & 111 & 0.12 \\
\hline Ductal1-7 & 428 & 2.05 & Ductal 2-7 & 423 & 2.09 & Ryerson-7 & 199 & 2 & King-7 & 123 & 0.18 \\
\hline Ductal1-8 & 380 & 1.56 & Ducta/2-8 & 370 & 1.9 & Ryerson-8 & 227 & 2.28 & King-8 & 98 & 0.1 \\
\hline Ductal1-9 & 419 & 1.56 & Ductal2-9 & 351 & 1.72 & Ryerson-9 & 243 & 1.48 & King-9 & 186 & 0.24 \\
\hline Ductal1-10 & 481 & 1.28 & Ductal2-10 & 354 & 1.9 & Ryerson-10 & 272 & 1.35 & King-10 & 153 & 0.25 \\
\hline Ductal1-11 & 404 & 1.69 & Ductal2-11 & 382 & 1.77 & Ryerson-11 & 253 & 1.38 & King-11 & 141 & 0.49 \\
\hline Ductal1-12 & 377 & 1.94 & Ductal2-12 & 390 & 2.04 & Ryerson-12 & 276 & 0.51 & King-12 & 130 & 0.14 \\
\hline Ductal1-13 & 374 & 1.75 & Ductal2-13 & 413 & 1.69 & Ryerson-13 & 258 & 0.5 & King-13 & 163 & 0.38 \\
\hline Ductal1-14 & 417 & 1.94 & Ductal2-14 & 393 & 1.75 & Ryerson-14 & 315 & 0.44 & King-14 & 98 & 0.32 \\
\hline
\end{tabular}

+ Ductal1-2 means, Ductal concrete type $A$ beam and $2^{\text {nd }}$ test. 
Table 4.2: Max Load-Deflection Type B beam

\begin{tabular}{|c|c|c|c|c|c|c|c|c|c|c|c|}
\hline Type of & Max. & Max. & Type of & Max. & Max. & Type of & Max. & Max. & Type of & Max. & Max. \\
\hline Mix & Load & Deflection & Mix & Load & Deflection & Mix & Load & Deflection & Mix & Load & Deflection \\
\hline & $\overline{(\mathrm{KN})}$ & $(\mathrm{mm})$ & & $(\mathrm{KN})$ & $(\mathrm{mm})$ & & (KN) & $(\mathrm{mm})$ & & (KN) & $(\mathrm{mm})$ \\
\hline Ductal 1-1 & 410 & 2.07 & Ductal2-1 & 376 & & rson-1 & 429 & 2.7 & king-1 & 236 & 2.15 \\
\hline Ductal 1-2 & 370 & 2.75 & Ductal2-2 & 353 & 2.17 & Ryerson- 2 & 407 & 2.38 & King-2 & 205 & 2.1 \\
\hline Ductal1-3 & 309 & 1.97 & Ductal 2-3 & 416 & 2.4 & Ryerson-3 & 359 & 2.24 & King-3 & 183 & 3.26 \\
\hline Ductal 1-4 & 372 & 1.43 & Ductal 2-4 & 410 & 2.37 & Ryerson-4 & 369 & 2.44 & King-4 & 142 & 3.13 \\
\hline
\end{tabular}

Table 4.3: Max Load-Deflection Type $B$ beam ( $a / d=1.74)$

\begin{tabular}{|c|c|c|}
\hline Mix & Max & Max \\
\hline Type & Load & Deflection \\
\hline & (KN) & (mm) \\
\hline Ductal1-1 & 482 & 2.11 \\
\hline Ductal1-2 & 671 & 2.25 \\
\hline Ductal1-3 & 535 & 2.22 \\
\hline
\end{tabular}

Table 4.4: Max Load-Deflection Type B beam ( $a / d=1.4$ )

\begin{tabular}{|c|c|c|c|c|c|c|c|c|c|c|c|}
\hline Mix & Max & Max & Mix & Max & Max & Mix & Max & Max & Mix & Max & Max \\
\hline Type & Load & Deflection & Type & Load & Deflection & Type & Load & Deflection & Type & Load & Deflection \\
\hline & (KN) & $(\mathrm{mm})$ & & $\overline{(K N)}$ & $(\mathrm{mm})$ & & (KN) & $(\mathrm{mm})$ & & $\overline{(\mathrm{KN})}$ & $(\mathrm{mm})$ \\
\hline Ductal1-1 & 799 & 1.14 & Ductal2-1 & 753 & 88 & Ryerson-1 & 709 & 2.02 & King-1 & 357 & 1.55 \\
\hline Ductal1-2 & 678 & 1 & Ductal2-2 & 598 & 2.07 & Ryerson-2 & 704 & 1.79 & King-2 & 388 & 1.59 \\
\hline Ductal1-3 & 622 & 2.15 & Ductal2-3 & 863 & 1.57 & Ryerson-3 & 762 & 2.57 & King-3 & 370 & 1.49 \\
\hline
\end{tabular}

Table 4.5: Max Load-Deflection Type B beam (a/d=1.0)

\begin{tabular}{|c|c|c||c|c|c||c|c|c||c|c|c|}
\hline Mix & Max & Max & Mix & Max & Max & Mix & Max & Max & Mix & Max & Max \\
\hline Type & Load & Deflection & Type & Load & Deflection & Type & Load & Deflection & Type & Load & Deflection \\
\hline & $(\mathrm{KN})$ & $(\mathrm{mm})$ & & $(\mathrm{KN})$ & $(\mathrm{mm})$ & & $(\mathrm{KN})$ & $(\mathrm{mm})$ & $\cdots$ & $(\mathrm{KN})$ & $(\mathrm{mm})$ \\
\hline Ductal1-1 & 1145 & 1.9 & Ductal2-1 & 1414 & 1.53 & Ryerson-1 & 1292 & 1.41 & King-1 & 488 & 2.04 \\
\hline Ductal1-2 & 1278 & 2.13 & Ductal2-2 & 1366 & 1.69 & Ryerson-2 & 1050 & 1.65 & King-2 & 411 & 1.95 \\
\hline Ductal1-3 & 1371 & 2.15 & Ductal2-3 & 1137 & 1.6 & Ryerson-3 & 1071 & 3.18 & King-3 & 602 & 1.4 \\
\hline
\end{tabular}




\subsection{Failure Modes}

Fig. 4.1 represents the failure modes of different concrete beams. Failure mode of Type A and Type B beam show a typical flexure type of failure, where Type $B$ beam with a/d ratio between 1.0 to 1.74 shows a shear failure pattern. .

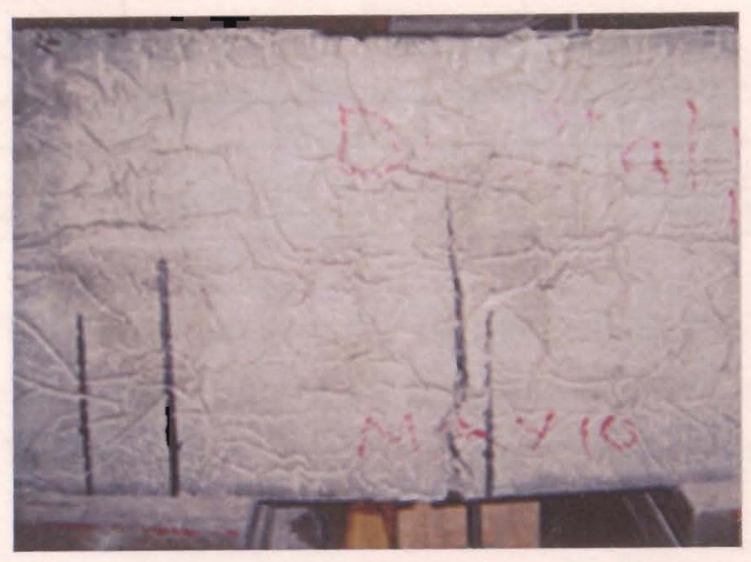

Failure mode type A beam

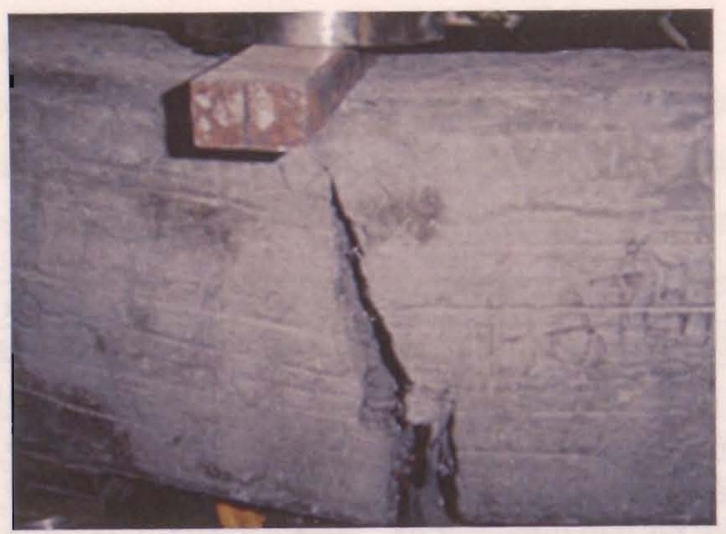

Failure mode, $\mathrm{a} / \mathrm{d}=1.74$

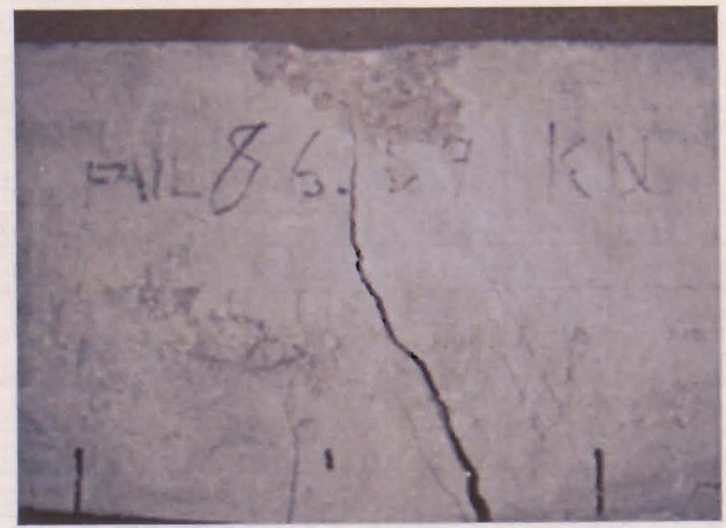

Failure mode $a / d=1.0$

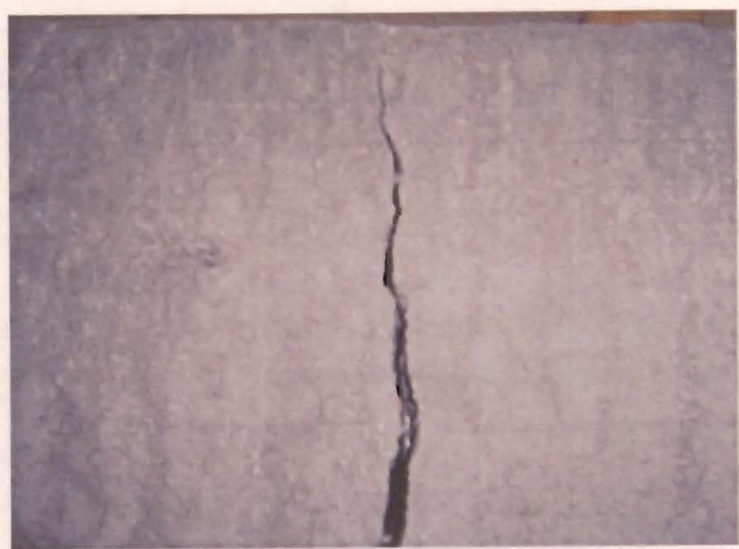

Failure mode type $\mathbf{B}$ beam

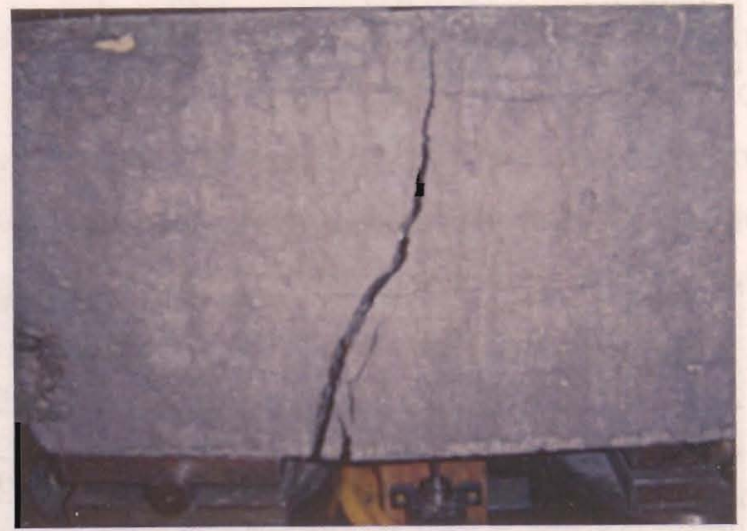

Failure mode,$a / d=1.4$

Fig. 4.1: Beams showing failure pattern for various concrete mixes 


\section{Chapter 5}

\section{Analysis of Experimental Results}

\subsection{Effect of Concrete Type/ Strength on Load-Deflection Response of Beams}

Figure 5.1 and figure 5.2 show the average load-deflection response of beam specimens and effect of concrete strength/types on response. It is seen that the Ultra high-performance concrete (UHSC/UHPC) beams (Ductal1, Ductal2, Ryerson having compressive strength of $150 \mathrm{MPa}, 175 \mathrm{MPa}$, $135 \mathrm{MPa}$, respectively) have higher load and deflection capabilities than those of high-strength concrete (HSC) (a compressive strength of $70 \mathrm{MPa}$ ). There is not much difference in deflection pattern can be observed in Type A and Type B beams. It is observed that with the increase of concrete strength, the loading capacity of UHSC beams increase up to certain limit and then remains almost constant until it fails showing better ductility. The enhanced strength and ductility performance of UHSC can be attributed to the concrete characteristics such as high strength and presence of fibre in the matrix. .
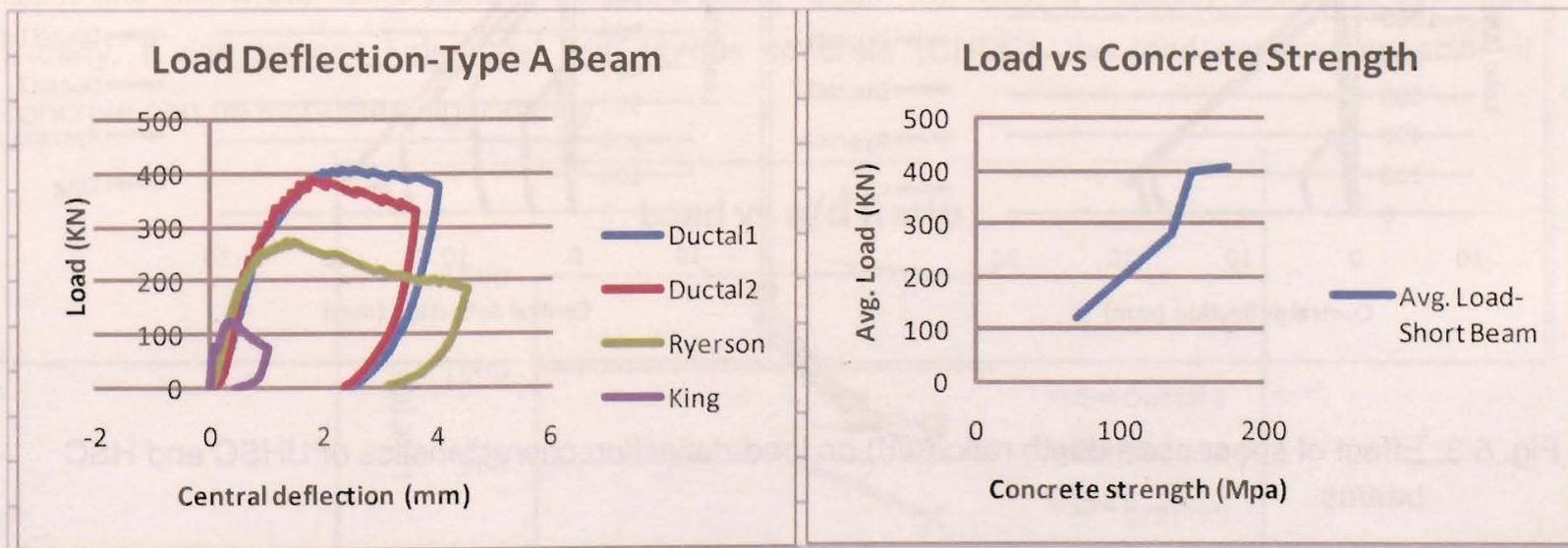

Fig. 5.1: Comparative load-deflection characteristics of UHSC and HSC beams 


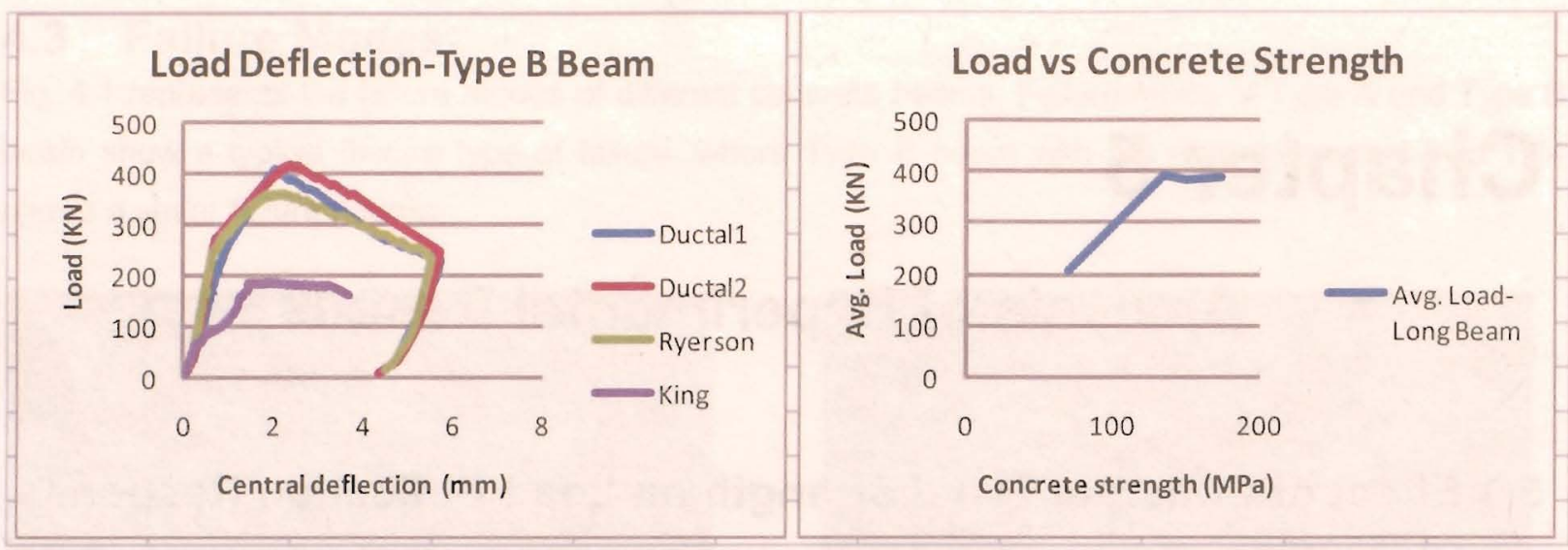

Fig. 5.2: Comparative load-deflection characteristics of UHSC and HSC beams

Figure 5.3 shows that load-deflection capability of different concrete mix for a specific a/d ratio and Figure 5.4 shows the load deflection behavior of a specific concrete mix for different a/d ratio. For a specific a/d ratio, load deflection capabilities of HSC and UHSC follow the same pattern but load carrying capacity increases with the increase of concrete strength. The same observation can be made for beams with a specific mix for different a/d ratio. It is seen that initial stiffness of the HSC and UHSC is very high.
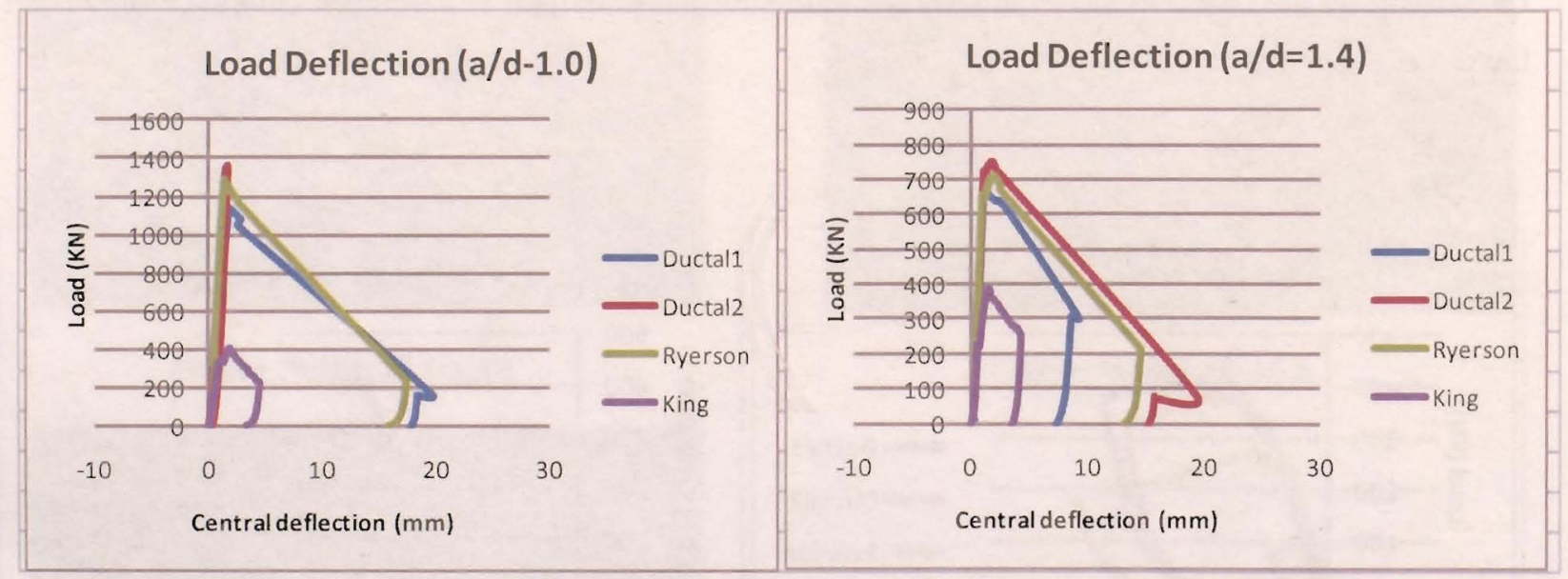

Fig. 5.3: Effect of shear span depth ratio (a/d) on load-deflection characteristics of UHSC and HSC beams. 


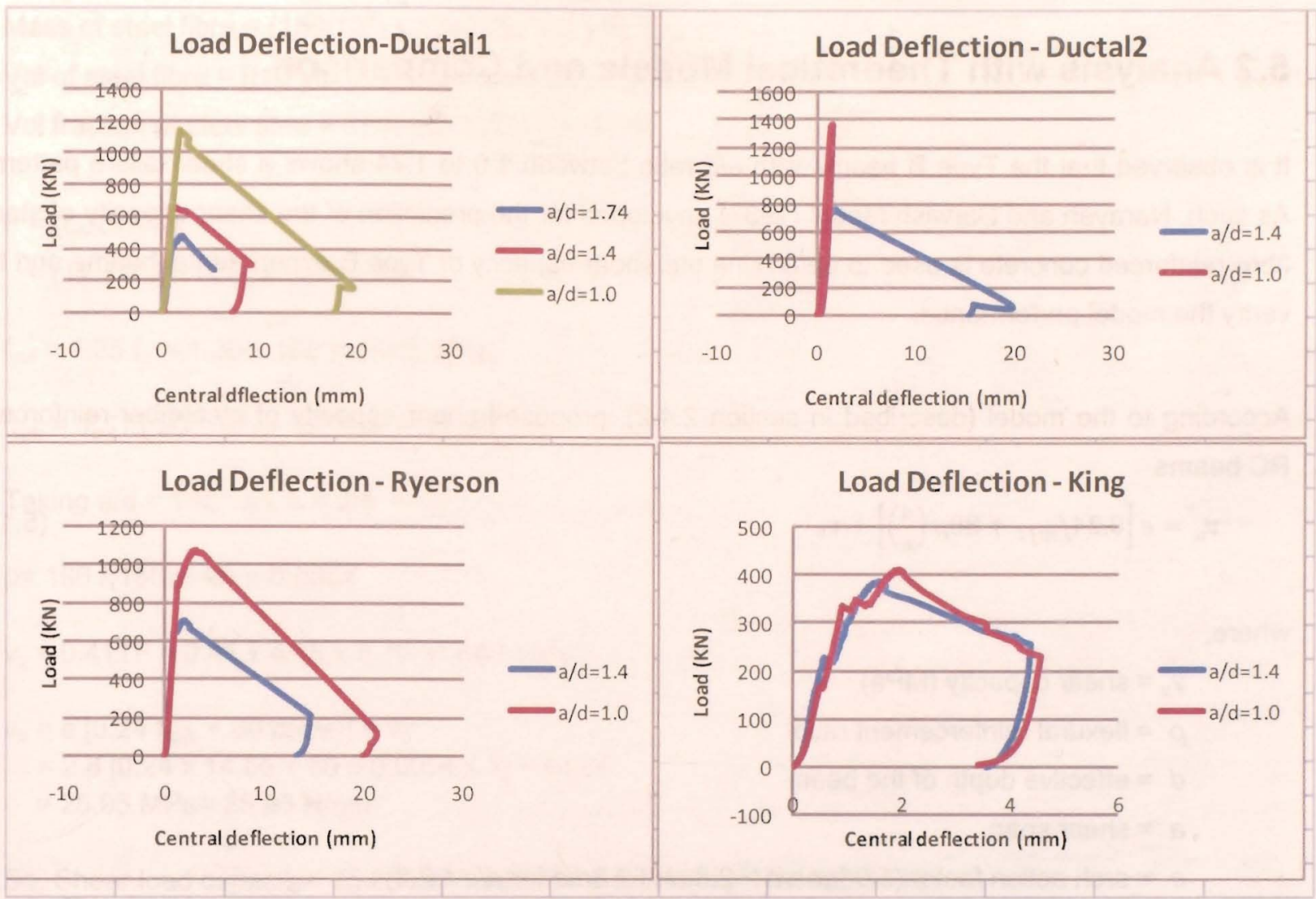

Fig. 5.4: Effect of shear span depth ratio (a/d) on load-deflection characteristics of UHSC and HSC beams

From Fig. 5.5 it is seen that the load capacity of HSC/UHSC e decreases with the increase of a/d ratio, and follow the same pattern. For HSC (King) beam the loading capacity seems to decrease linearly. It can be concluded that with fibrous concrete (UHSC), the load carrying capacity of concrete can be increased significantly.

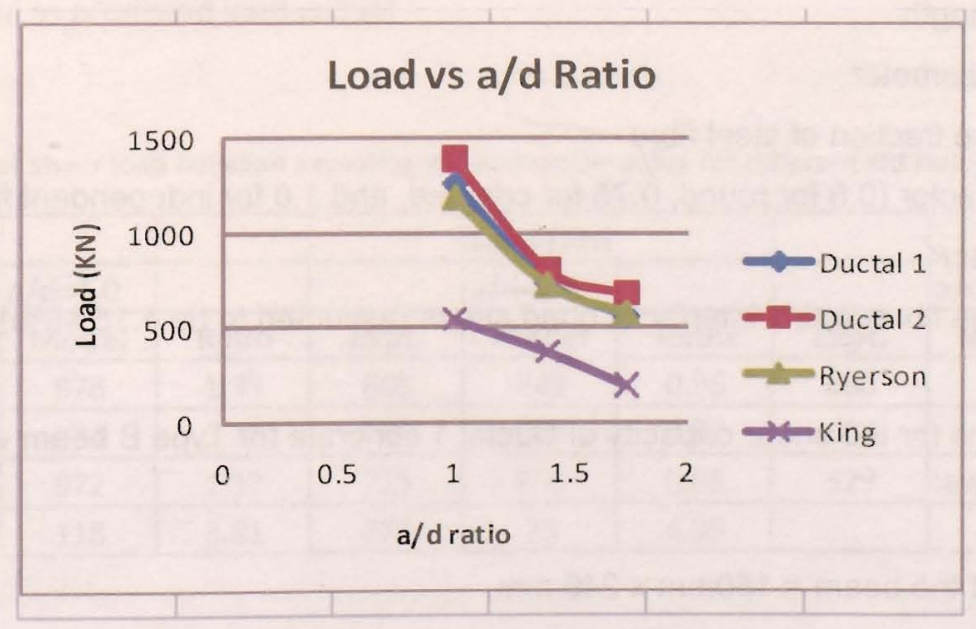

Fig. 5.5: Behavior of concrete with a/d ratio 


\subsection{Analysis with Theoretical Models and Comparison}

It is observed that the Type B beams with a/d ratio between 1.0 to 1.74 shows a shear failure pattern. As such, Narayan and Darwish Model (1987) developed for the prediction of the shear capacity of steel fibre reinforced concrete is used to determine the shear capacity of Type B experimental beams and to verify the model performance.

According to the model (described in section 2.4.2), proposed shear capacity of steel-fiber-reinforced RC beams

$$
v_{u}=e\left[0.24 f_{s p f c}+80 \rho\left(\frac{d}{a}\right)\right]+v_{b} .
$$

where,

$v_{u}=$ shear capacity $(\mathrm{MPa})$

$\rho=$ flexural reinforcement ratio

$d=$ effective depth of the beam

$a=$ shear span

$e=\operatorname{arch}$ action factor $(1.0$ for $a / d>2.8$ and $2.8 d / a$ for $a / d \leq 2.8$ )

$f_{\text {spfc }}=$ split cylinder strength $(\mathrm{MPa})$

$$
f_{s p f c}=\frac{f_{c u f}}{(20-\sqrt{F})}+0.7+\sqrt{F}
$$

where,

$f_{c u f}=$ cube strength of fibre concrete and

$F=\left(L_{f} / D_{f}\right) V_{f} d_{f}$, in which,

$L_{f}=$ fibre length

$D_{f}=$ fibre diameter

$V_{f}=$ volume fraction of steel fibre

$d_{f}=$ bond factor $(0.5$ for round, 0.75 for crimped, and 1.0 for independent fibre)

Again, $v_{b}=0.41 \tau F$

Where, $T=$ average fibre-matrix interfacial bond stress (assumed to be $4.15 \mathrm{MPa}$ )

Sample calculations for the shear capacity of Ductal 1 concrete for Type B beam with $a / d=1.0$ is presented as follows:

$X$-sectional area of the beam $=150 \mathrm{~mm} \times 240 \mathrm{~mm}$

Vol of concrete $=\mathrm{Vol}$. of beam - Vol. of longitudinal bar $-\mathrm{Vol}$. of stirrups

$$
=21600000 \mathrm{~mm}-141878-117640=1340482 \mathrm{~mm}^{3}
$$


Mass of steel fibre $=\left(156 / 10^{9}\right) \times 1340482=3.329 \mathrm{~kg}$

Vol of steel fibre $=\left[\left(10^{9} / 8750\right) \times 3.329\right]=380457 \mathrm{~mm}^{3}$

Vol fraction of steel fibre $=380457 / 1340482=0.28$

$F=\left(L_{f} / D_{f}\right) V_{f} d_{f}$

$=(12.5 / 0.2) \times 0.28 \times 0.5=8.75$

$f_{\text {cuf }}=1.25 f_{c}^{\prime}=1.25 \times 150=187.5 \mathrm{MPa}$

$f_{\text {spfc }}=f_{\text {cuf }} /(20-\sqrt{F})+0.7+\sqrt{F}=14.66$

Taking $a / d=1.0 ;$ so, $e=2.8$

$\rho=196 /(150 \times 240)=0.0054$

$v_{b}=0.41 \mathrm{TF}=0.41 \times 4.15 \times 8.75=14.89 \mathrm{MPa}$

$v_{\mathrm{u}}=\mathrm{e}\left[0.24 f_{\mathrm{spfc}}+80 \rho(\mathrm{d} / \mathrm{a})\right]+\mathrm{v}_{\mathrm{b}}$

$=2.8[0.24 \times 14.66+80 \times 0.0054 \times 1]+14.89$

$=25.95 \mathrm{MPa}=25.95 \mathrm{~N} / \mathrm{mm}^{2}$

So, Shear load capacity $=25.85 \times(150 \times 240)=930.54 \times 10^{3} \mathrm{~N}=930.54 \mathrm{KN}$

The values of experimental loads are compared with those obtained from the model in table 5.1. Figure 5.6 shows the comparison of experimental and model predicted loads for a specific a/d ratio of $1.0,1.4$ and 1.74. Experimentally predicted load was higher compared to theoretically predicted load predicted by Narayan and Darwish model for beams with a/d ratio 1.0. However, for beams with $\mathrm{d} / \mathrm{d}$ of ratio > 1.0, the model seems to over predict the shear capacity. Reasonably, Narayan and Darwish model failed to predict (significantly under predicted) the shear capacity of HSC (King) beams without fibre as the ratio experimental to predicted load is 3.81 .

Table 5.1: Comparison of shèar load between experimental and model value for different ald ratio)

\begin{tabular}{|c|c|c|c|c|c|c|c|c|c|}
\hline Type of & & & & & Load (KN) & & & & \\
\hline Concrete & & $a / d=1.0$ & & & $a / d=1.4$ & & & $a / d=1.74$ & \\
\hline Mix & Expt. & Model & Ratio & Expt. & Model & Ratio & Expt. & Model & Ratio \\
\hline Ductal 2 & 1305 & 978 & 1.33 & 808 & 843 & 0.96 & 680 & 779 & 0.87 \\
\hline Ductal 1 & 1264 & 934 & 1.35 & 700 & 809 & 0.87 & 603 & 752 & 0.8 \\
\hline Ryerson & 1137 & 972 & 1.17 & 725 & 855 & 0.85 & 529 & 800 & 0.66 \\
\hline King & 450 & 118 & 3.81 & 372 & 75 & 4.96 & & & \\
\hline
\end{tabular}




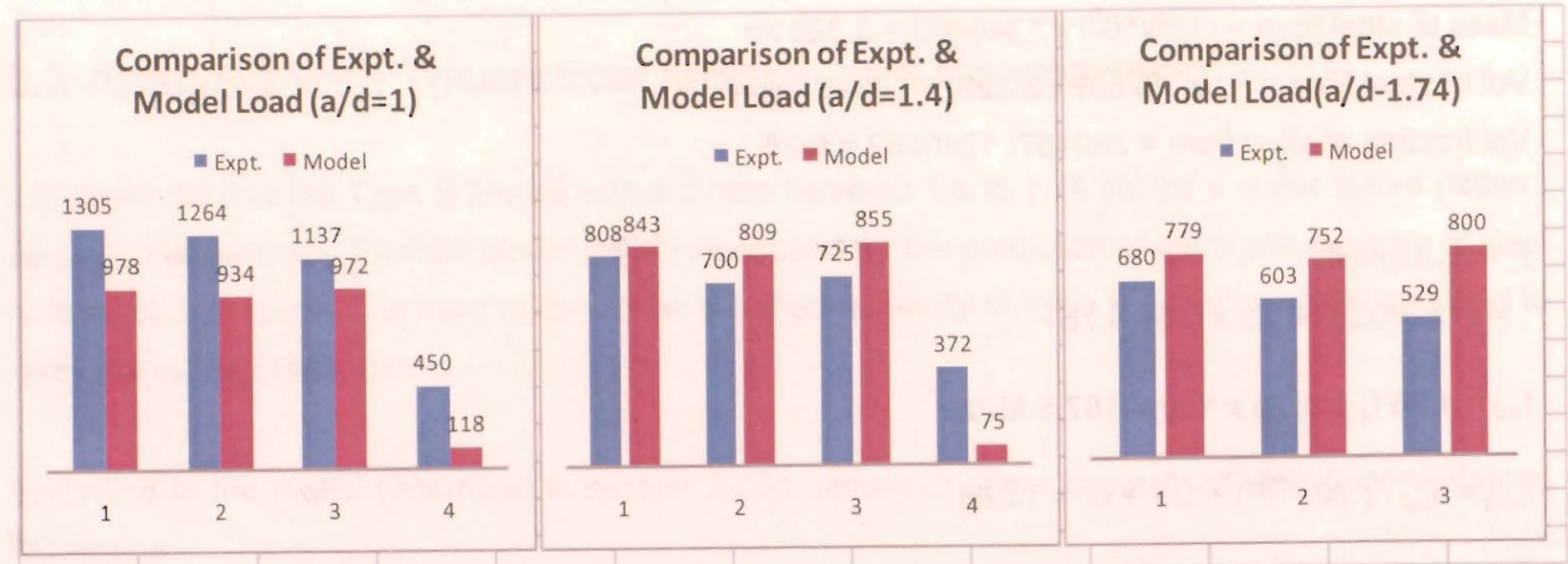

Fig. 5.6: Behavior of concrete with a/d ratio

There are other theoretical models as described in chapter 2 to find the shear capacity of HSC/UHSC beams, but this is outside the scope of the current project. 


\section{Chapter 6}

\section{Conclusion and Recommendations}

\subsection{Conclusion}

Load-deflection behaviour and strength characteristics of reinforced beams with high and ultra high strength concretes are studied based on experimental investigation. The effect of concrete types (HSC or UHSC), concrete compressive strength (70 MPa to $175 \mathrm{MPa}$ ) and span to depth ratio (a/d) were studied. Four concretes including one high strength and three ultra high strength concrete were considered for the construction of experimental beam specimens. High strength concrete (HSC) was based on coarse aggregate with a compressive strength of $70 \mathrm{MPa}$ while fibre reinforced ultra high strength concrete (UHSC) with no coarse aggregate had strength ranging between $135 \mathrm{MPa}$ and 175 MPa. Two different cross-sections of reinforced beams namely Type A and Type B were considered for testing. All the load tests were conducted under single point loading and their load carrying capacities with deflections were compared. Three sets of Type B beam were tested with three different shear spans to depth ratio (a/d) of 1.0, 1.4 and 1.74 for each concrete mix. The following conclusions are drawn from the study:

- The strength of HSC/UHSC beams increases with the increase of concrete compressive strength

- The initial stiffness and ductility of fiber reinforced UHSC beams are found to be high compared with HSC (no fiber) beams with lower strength.

- The shear capacity of HSC/UHSC beams decreases with the increase of a/d. However, the trend of decrease is observed to be non-linear for UHSC and linear for HSC.

- The theoretical model proposed by Naryan and Drawish (1987) under-predicted the shear capacity of UHSC beam with a/d $=1.0$ but over-predicted the shear capacity of beam with $a / d>1.0$. Research is needed to develop theoretical models specifically suitable for UHSC.

\subsection{Recommendations for Future Work}

Both the literature review and this study show that study on the strength and ductility behaviour of fibre reinforced UHSC/UHPC beams is still very limited. The following are some recommendations for future investigations: 
Conduct beam tests without any shear or main reinforcement to determine the flexure and shear strength of HSC/UHSC beams and develop theoretical models/code based provisions/modifications for design purposes.

Conduct further research to determine the long term durability and structural performance of HSC/UHSC in an aggressive environment. 


\section{REFERENCES}

$\mathrm{ACl}$ Committee 318, "Building Code Requirements for Structural Concrete (ACl 318-05) and Commentary (318R-05)," American Concrete Institute, Farmington Hills, MI, 2005, 430 pp.

ACl Committee 544 (1988), "Design considerations for steel fibre reinforced concrete", $A C l$ Structural Journal, 85(5), 563-580.

ACl Committee 544, "Report on Fiber-Reinforced Concrete (ACl 544.1R-82)," American Concrete Institute, Farmington Hills, MI, 1982, 21 pp.

Aoude, H., Belghiti, M., and Mitchell, D. (2008), "Predicting the shear resistance of SFRC beams", CSCE Annual Conference, Quebec, Canada, June 10-13, 2008.

Barr, B. and Lee, K. (2004), "FRC Guidelines in the UK, with Emphasis on SFRC in Floor Slabs," Proceeding of the North American/European Workshop on Advances in Fiber Reinforced Concrete, BEFIB 2004, Bergamo, Italy, Sept. 2004, pp. 29-38.

Bazant, Z. and Kim J. (1984), "Size effect in shear failure of longitudinally reinforced beams", $A C I$ Structural Journal, 81(5), 456-468.

Benjamin, G. and Jussara, T.(2007), "Durability of an Ultrahigh-Performance Concrete", Journal of Materials in Civil Engineering, 19(10).

Calixto, M., Filho, V., and Goncalvez, M. (2002), "Shear behaviour of reinforced concrete beams with addition of short steel fibre", Proceeding of the 3rd International Conference on HighPerformance Concrete: Performance and Quality of Concrete Structure, Recife, Pernambuco, Brazil, 4-6 October 2002. Edited by V.M. Malhorta. ACl, Farmington Hills, Mich. SP-207, pp. 449- 466 .

Campione, G., Mendola, L., and Papia, M. (2006), "Shear strength of steel fibre reinforced concrete beams with stirrups". Structural Engineering and Mechanics, 24(1), 107-136.

CEN. 1992. Eurocode 2," Design of concrete structure. Part 1: General rules and rules for buildings", European Committee for Standardization (CEN), Brussels, Belgium.

Chote, S: and Barzin, M. (2009), "Flexural Design of Fiber-Reinforced Concrete," ACl Materials Journal, 106(5).

CSA. 2004. CSA A23.3-04: Design of Concrete Structures, Canadian Standards Association.

di Prisco, M., Toniolo, G., Plizzari, A., Cangiano, S. and Failla, C. (2004), "Italian Guidelines on SFRC," Proceedings of the North American/European Workshop on Advances in Fiber Reinforced Concrete, BEFIB 2004, Bergamo, Italy, Sept. 2004, pp. 39-72. 
Dupont, D. and Vandewalle, L. (2003), "Shear capacity of concrete beams containing longitudinal reinforcement and steel fibres", Proceeding of Innovations in Fibre-Reinforced Concrete for Value, Detroit, Mich. Edited by N. Banthia. ACl, Farmington Hills, Mich. SP-216, pp. 79-94.

Dupont, D. (2003)," Modelling and experimental validation of the constitutive law and cracking behavior of steel fibre reinforced concrete", Catholic University of Leuve, Heverlee, Belgium, 2003.

Fischer, G. (2004), "Current U.S. Guidelines on Fiber Reinforced Concrete and Implementation in Structural Design", Proceedings of the North American/ European Workshop on Advances in Fiber Reinforced Concrete, BEFIB 2004, Bergamo, Italy, Sept. 2004, pp. 13-22.

Foster, J. (2001) "On behavior of high-strength concrete columns: Cover spalling, steel fibres, and ductility", ACI Structural Journal, 98(4), 583-589.

Ghali, A., and Favre, R.(1986), "Concrete Structures: Stresses and Deformations", Chapman and Hall, London, UK, 1986, $352 \mathrm{pp}$.

Harajili, M., Hout, M., and Jalkh, W. (1995), "Local bond stress-slip behavior of reinforcing bars embedded in plain and fibre concrete", ACl Material Journal, 4(1), 343-353.

Hassoun, N. and Sahebjam, K. (1985), "Plastic Hinge in Two-Span Reinforced Concrete Beams Containing Steel Fibers," Proceedings of the Canadian Society for Civil Engineering, 1985, pp. 119-139.

Henager, H. and Doherty, J. (1976), "Analysis of Reinforced Fibrous Concrete Beams,".

Proceedings, ASCE, V. 12, No. ST1, 1976, pp. 177-188.

Japan Society of Civil Engineers (1984), "Methods of Tests for Flexural Strength and Flexural Toughness of Steel Fiber Reinforced Concrete (JSCE-SF4), Concrete Library International, Part III-2, 3, 1984, pp. 58-61:

Majdzadeh, F., Soleimani, S., and Banthia, N. (2006), "Shear strength of reinforced concrete beams with a fiber concrete matrix", Canadian Journal Civil Engineering 33, 726-734.

Mirsayah, A. and Banthia N. (2002), "Shear strength of steel fibre-reinforced concrete", $A C l$ Materials Journal, 99 (5): 473-479.

Naaman, E. (2003), "Strain hardening and deflection hardening fibre reinforced composites", proceedings of IV Intern, RILEM Workshop, "High performance fibre reinforced cement composites (HPFRCC4)", Ann Árbour, MI, US, 2003, 95-113.

Narayanan, R. and Darwish S. (1987), "Use of Steel Fibres as Shear Reinforcement", $A C l$ Structural Journal, 84(3): 216-227.

Nehdi, M., Chabib H., and Said, A. (2007), "Proposed Shear Design Equations for FRP-Reinforced Concrete Beams Based on Genetic Algorithms Approach", Journal of Materials in Civil 
Engineering, 9)(12).

Newhook, J. and Svecova, D. (2006), "Reinforcing Concrete Structures with Fibre-Reinforced Polymer", Winnipeg: ISIS Canada Corporation.

Parant, E. (2003), "Mécanismes d'Endommagement et Comportements Mécaniques d'un Composite Cimentaire Fibré Multi-Échelles sous Sollicitations Sévères: Fatigue, Choc, Corrosion," PhD thesis, Ecole Nationale des Ponts et Chaussées, 2003, 245 pp. (in French).

Pimienta, P. and Chanvillard, G. (2004), "Retention of the Mechanical Performances of Ductal@ Specimens Kept in Various Aggressive Environments," Proceedings, fib international Symposium-Concrete Structures: the Challenge of Creativity, 2004, Avignon, France, pp 6.

RILEM TC 162-TDF. (2000), "Recommendations of RILEM TC 162-TDF: sigma-epsilon design method", Materials and Structures, 33: 75-81.

RILEM TC 162-TDF. (2003), "Recommendations of $\sigma-\varepsilon$ design method of SFRC", Materials and Structures, 36: 560-567.

Rossi, P. (1998), "Ultra-high Performance Concrete-A summary of Current Knowledge", Concrete International, February 2008.

Rossi, P. (1998), "Les Bétons de Fibres Métalliques", Presses de l'Ecole Nationale des Ponts et Chaussée, pp 308 (in French).

SETRA, 2002. "Ultra-High Performance Fibre-Reinforced Concretes", AFGC/SETRA Interim Recommendations, SETRA, 2002, pp 114.

Soranakom, C. (2008), "Multi-Scale Modeling of Fiber and Fabric Reinforced Cement Based Composites", PhD dissertation, Arizona State University, Tempe, AZ, 2008, pp 477.

- Soranakom, C. and Mobasher, B. (2007), “Closed-Form Solutions for Flexural Response of FiberReinforced Concrete Beams," Journal of Engineering Mechanics, V. 133, No. 8, Aug. 2007, pp. 933-941.

Soranakom, C. and Mobasher, B. (2008), "Development of Design Guidelines for Strain Softening Fiber Reinforced Concrete, ${ }^{n} 7$ th RILEM International Symposium on Fibre Reinforced Concrete, BEFIB 2008, Chennai (Madras), India, Sept. 2008, pp. 513-523.

Swamy, N. and Al-Ta'an, A. (1981), "Deformation and Ultimate Strength in Flexural of Reinforced Concrete Beams Made with Steel Fiber Concrete," ACI Structural Journal, 78(5), Sept.-Oct. 1981, pp. 395-405.

Swamy, N., Mangat, S., and Rao, K. (1975), "The Mechanics of Fiber Reinforced Cement Matrices," Fiber Reinforced Concrete, SP-44, American Concrete Institute, Farmington Hills, MI, 1975, pp. 1-28.

Tailhan, L., Rossi, P., Parant, E., Clement, L., and Arca, A. (2004) "Uniaxial Tension Behavior of a Cement Composite with Strain Hardening Based on an Inverse Approach," Bulletin de Laboratores des Ponts et Chaussées, No. 248, Jan.-Feb. 2004, pp. 35-48. 
Teutsch, M. (2004), "German Guidelines on Steel Fiber Concrete," Proceeding of the North American/European Workshop on Advances in Fiber Reinforced Concrete, BEFIB 2004, Bergamo, Italy, Sept. 2004, pp. 23-28.

Tompos, J. and Frosch, J. (2002), "Influence of beam size, longitudinal reinforcement, and stirrups effectiveness on concrete shear strength", ACI Structural Journal, 99(5), 559-576.

Valle, M. and Buyukozturk, O. (1993), "Behavior of fibre reinforced high-strength concrete under direct shear", ACI Structural Journal, 90(2), 122-133.

Vandewalle, L. et al., "Design of Steel Fibre Reinforced Concrete Using the $\sigma-w$ Method: Principle and Applications," Materials and Structures, V. 35, No. 249, June 2002, pp. 262-278.

Vandewalle, L. et al., "Test and Design Methods for Steel Fibre Reinforced Concrete. Recommendations for Bending Test," Materials and Structures, Vol. 33, No. 225, Jan. 2000 , pp. 3-5.

Vandewalle, L. et al., "Test and Design Methods for Steel Fibre Reinforced Concrete: Recommendations for $\sigma-\varepsilon$ Design Method," Materials and Structures, Vol. 33, No. 226, Mar. 2000, pp. 75-81.

Vandewalle, L. et al., "Test and Design Methods for Steel Fibre Reinforced Concrete-Final Recommendation," Materials and Structures, V. 35, No. 253, Nov. 2002, pp. 579-582.

Vandewalle, L. et al., "Test and Design Methods for Steel Fibre Reinforced Concrete- $\sigma-\varepsilon$ Design Method-Final Recommendation," Materials and Structures, V. 36, No. 262, Oct. 2003, pp. 560- 567.

Wang, Z., Liu, Y., and Shen, R. (2008), “Stress-strain relationship of steel fibre-reinforced concrete under dynamic compression". Construction and Building materials. Vol 22, pp. 811-819. 